\title{
Four new filamentous fungal species from newly-collected and hive- stored bee pollen
}

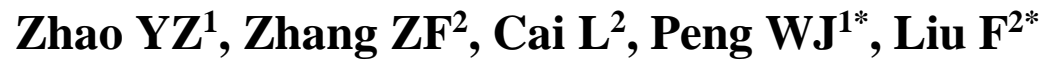 \\ ${ }^{1}$ Institute of Apicultural Research, Chinese Academy of Agricultural Sciences, Beijing 100093, China \\ ${ }^{2}$ State Key Laboratory of Mycology, Institute of Microbiology, Chinese Academy of Sciences, Beijing 100101, China
}

Zhao YZ, Zhang ZF, Cai L, Peng WJ, Liu F 2018 - Four new filamentous fungal species from newly-collected and hive-stored bee pollen. Mycosphere 9(6), 1089-1116, Doi 10.5943/mycosphere/9/6/3

\begin{abstract}
Hive-stored pollen, as one of the major nutrition sources for honeybees, is the mixture of fresh bee pollen with honey, plant resins and wax. In this study, four new species (i.e. Arthrinium locuta-pollinis, Chrysosporium alvearium, Nigrograna locuta-pollinis and Trichoderma pollinicola) were identified, when we explored the culturable fungi in newly-collected bee pollen and hive-stored pollen produced by Italian honey bees (Apis mellifera ligustica) in the flowering season of rape (Brassica campestris). The four new species were described on the basis of morphological comparisons and multi-locus phylogenetic analyses, and their relationships with morphologically similar and phylogenetically closely related taxa are discussed.
\end{abstract}

Key words - Arthrinium - Chrysosporium - Morphology - Nigrograna - Phylogenetic analyses Trichoderma

\section{Introduction}

Bee pollen, one of the products obtained from the hive due to the activity of honeybees, is abundant in organic molecules, with demonstrated antifungal, antibacterial, antiviral, antiinflammatory, immune stimulating and analgesic activities (Kroyer \& Hegedus 2001, AlmarazAbarca et al. 2004). Newly-collected bee pollen is not always served as the direct food source for honey bees. Bee pollen is sometimes stored in comb cells of hives for a few days, mixing with honey, plant resins and wax, and then consumed by honey bees (Brovarskyi et al. 2017, Kieliszek et al. 2018). During this process, bacteria and yeasts have been considered playing an important role on lactic acid fermentation (Foote 1957, Haydak 1958, Gilliam 1979). However, filamentous fungi thus far received rare attention in apicultural research even they are widely known for their ability to degrade and synthesize numerous compounds (Gilliam et al. 1989).

Up to now, only a few fungal taxa have been reported from newly-collected bee pollen and hive-stored pollen based on morphological identification, such as Alternaria alternata, Aspergillus spp., Aureobasidium pullulans, Bettsia alvei, Cladosporium oxysporum, Epicoccum purpurascens, Eremascus fertilis, Fusarium oxysporum, Gymnoascus setosus, Monilia spp., Mucor erectus, Oospora favorum and Penicillium spp. (Egorova 1971, Sainger et al. 1978, Gilliam et al. 1989), and fungi associated with these two types of pollen remained poorly explored.

In our fungal exploration from newly-collected bee pollen and hive-stored pollen in the flowering season of Brassica campestris, four new filamentous species are discovered. They are 
described and illustrated based on the morphological comparisons and phylogenetic analyses in the present study. While the fungal community composition and distinction between these two kinds of bee pollen will be published elsewhere.

\section{Materials \& Methods}

\section{Sample collection and fungal isolation}

Newly-collected pollen and hive-stored pollen samples were collected from Italian honey bee (Apis mellifera ligustica) colonies located in Yicheng, Hubei province in China, where the blooming rape (Brassica campestris) covered more than 500 hectares in March 2016 (Fig. 1). Three colonies with consistent population were used to trap bee pollen and produce stored pollen. Each colony was comprised of 10 frames of adult bees (about 8000-10 000 adult bees). Before we established the bee colonies, no pollen was stored in beehives, but which contained some bee larvae and honey. New frames were placed in the colonies to provide space for the worker bees to store pollen.
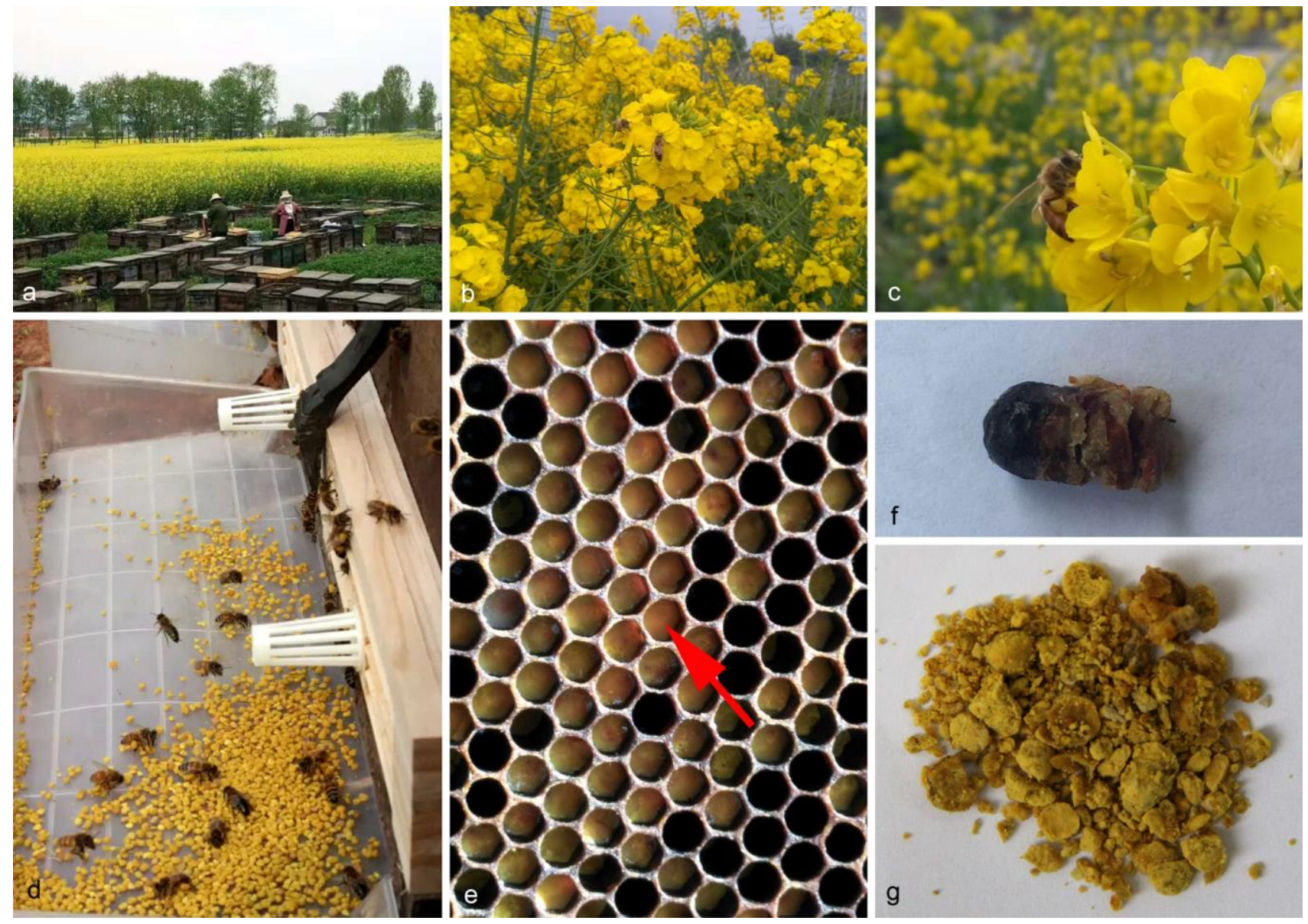

Figure 1 - Sampling site and samples. a Sampling site beside fields of Brassica campestris. b-c Worker bees (Apis mellifera ligustica) collecting pollen of rape flowers. d Newly-collected pollen obtained by pollen traps. e Red arrow indicating hive-stored pollen under fermentation in the comb cells. $\mathrm{f}-\mathrm{g}$ Hive-stored pollen.

In the flowering season of rape, standard pollen traps were used to collect bee pollen samples (Fig. 1) (Giesecke et al. 2010). Fresh bee pollen was immediately collected from pollen baskets (corbicula) of incoming honey bees. Fourteen days after the flowering season of rape, hive-stored pollen samples were dug by sterile medicine spoons (Kieliszek et al. 2018). One hundred grams of newly-collected pollen and hive-stored pollen samples were collected from each colony, which 
made 3 samples for each kind of pollen. All samples were put in sterile $10 \mathrm{~mL}$ centrifuge tubes and took back to laboratory immediately and preserved at $4{ }^{\circ} \mathrm{C}$.

Fungi were isolated following a modified dilution plate method from newly-collected and hive-stored pollen samples (Zhang et al. 2015). One gram of each sample was suspended in $10 \mathrm{~mL}$ sterile water in a $15 \mathrm{~mL}$ sterile centrifuge tube. The tubes were shaken by Vortex vibration meter thoroughly. The suspension was then diluted to a series of concentrations, i.e. $10^{-2}, 10^{-3}, 10^{-4}$ and $10^{-5}$. Two hundred microliters suspensions from each dilution were spread onto potato-dextrose agar (PDA, Aobox, ABX-00279) and yeast-peptone-dextrose agar (YPD) containing ampicillin (50 $\mu \mathrm{g} / \mathrm{mL}$ ) and streptomycin $(50 \mu \mathrm{g} / \mathrm{mL}$ ), onto De Man, Rogosa and Sharpe agar (MRS, Aobox, 02293) containing amphotericin $(8 \mu \mathrm{g} / \mathrm{mL})$, by three replicates.

All the plates were incubated at room temperature (ca. 25-28 ${ }^{\circ} \mathrm{C}$ ) for $1-4$ weeks, and from which the single colonies were picked up and inoculated onto new PDA plates every $2 \mathrm{~d}$. All fungal strains were stored at $4{ }^{\circ} \mathrm{C}$ in the LC Culture Collection (personal culture collection held in lab of Dr. Lei Cai) for further studies. The dry cultures of novel species were deposited in the Herbarium of Microbiology, Academia Sinica (HMAS), while living cultures were deposited in the China General Microbiological Culture Collection Center (CGMCC).

\section{Morphology}

Morphological characterization was made for isolates cultivated on potato dextrose agar (PDA; Difco), and alternatively on synthetic nutrient-poor agar (SNA, $1 \mathrm{~g} \mathrm{KH}_{2} \mathrm{PO}_{4}, 1 \mathrm{~g} \mathrm{KNO}$, 0.5 $\mathrm{g} \mathrm{MgSO}_{4} \cdot 7 \mathrm{H}_{2} \mathrm{O}, 0.5 \mathrm{~g} \mathrm{KCl}, 0.2 \mathrm{~g}$ glucose, $0.2 \mathrm{~g}$ sucrose, $0.6 \mathrm{ml} \mathrm{NaOH}(1 \mathrm{M})$ and $13.2 \mathrm{~g}$ agar/liter distilled water) or amended with double-autoclaved pine needles placed onto the agar surface (Smith et al. 1996), malt extract agar (MEA, malt extract (Oxoid CM0059) $50 \mathrm{~g}, \mathrm{ZnSO}_{4} \cdot 7 \mathrm{H}_{2} \mathrm{O}$ $0.01 \mathrm{~g}, \mathrm{CuSO}_{4} \cdot 5 \mathrm{H}_{2} \mathrm{O} 0.005 \mathrm{~g} /$ liter distilled water), and cornmeal agar (CMA, cornmeal $20 \mathrm{~g}$, peptone $20 \mathrm{~g}$, glucose $20 \mathrm{~g}$, agar $15 \mathrm{~g} /$ liter distilled water) according to the genus level placement of the novel species. Cultures were incubated at $25{ }^{\circ} \mathrm{C}$ and another five temperatures for Trichoderma $\left(15{ }^{\circ} \mathrm{C}, 20{ }^{\circ} \mathrm{C}, 30{ }^{\circ} \mathrm{C}, 37{ }^{\circ} \mathrm{C}, 40{ }^{\circ} \mathrm{C}\right)$ according to Jaklitsch \& Voglmayr (2015). Cultures were examined periodically for the development of reproductive structures. Microscopic preparations were made mounted on lactic acid, and at least 30 measurements per structure were documented and examined under a Nikon Eclipse 80i microscope using differential interference contrast (DIC). Taxonomic descriptions and nomenclature were deposited in MycoBank.

\section{Molecular analyses}

Total genomic DNA was extracted from fungal mycelia using a modified CTAB protocol (Guo et al. 2000). Multi genes were amplified and sequenced for each new species, and the primer sets were listed in Table 1. ITS, TEF 1- $a$ and TUB2 sequences were obtained for Arthrinium, LSU, ITS, CAL and RPB2 sequences obtained for Chrysosporium, LSU, ITS, RPB2 and TEF1- $a$ obtained for Nigrograna, and ITS, CAL, RPB2 and TEF1- $a$ obtained for Trichoderma. However, single ITS phylogenetic analysis was finally performed for Chrysosporium due to the lack of reference sequences of other loci. PCR amplification protocols were performed as described by Gao et al. (2017), but the denaturing temperatures were adjusted to $59{ }^{\circ} \mathrm{C}$ for $R P B 2$, and $55^{\circ} \mathrm{C}$ for the other loci. Purification and sequencing of PCR amplifications were carried out by the Omegagenetics Company, Beijing, China. MEGA 6.06 was used to obtain consensus sequences from DNA sequences generated from forward and reverse primers. All reference and novel sequences obtained in this study were deposited in NCBI's GenBank database (See supplementary file: Table S1). The alignments were deposited in TreeBASE (www.treebase.org, S22986).

Sequences alignment was performed with MAFFT 7, and was manually improved with MEGA 6.06. Bayesian inference (BI) and maximum likelihood (ML) methods were implemented in this study. Bayesian analyses were performed using MRBAYES 3.2.2 (Ronquist et al. 2012) as outlined by Liu et al. (2014). ML analyses were performed using RAXML 7.0.3 with 1000 replicates under the GTR-GAMMA model (Stamatakis 2006). 
Table 1 Primers used in this study

\begin{tabular}{|c|c|c|c|c|}
\hline Locus & Primer & Primer sequences 5' to $3^{\prime}$ & Orientation & Reference \\
\hline \multirow{2}{*}{$\begin{array}{l}\text { large subunit } \\
\text { ribosomal DNA } \\
\text { (LSU) }\end{array}$} & LR0R & ACCCGCTGAACTTAAGC & Forward & $\begin{array}{l}\text { Rehner \& } \\
\text { Samuels (1994) }\end{array}$ \\
\hline & LR5 & ATCCTGAGGGAAACTTC & Reverse & $\begin{array}{l}\text { Rehner \& } \\
\text { Samuels (1994) }\end{array}$ \\
\hline \multirow[t]{2}{*}{ ITS } & ITS1 & $\begin{array}{l}\text { TCCGTAGGTGAACCTGCG } \\
\text { G }\end{array}$ & Forward & $\begin{array}{l}\text { White et al. } \\
\text { (1990) }\end{array}$ \\
\hline & ITS4 & $\begin{array}{l}\text { TCCTCCGCTTATTGATAT } \\
\text { GC }\end{array}$ & Reverse & $\begin{array}{l}\text { White et al. } \\
\text { (1990) }\end{array}$ \\
\hline \multirow[t]{3}{*}{$\begin{array}{l}\text { beta-tubulin } \\
(T U B 2)\end{array}$} & $\mathrm{T} 1$ & $\begin{array}{l}\text { AACATGCGTGAGATTGT } \\
\text { AAGT }\end{array}$ & Forward & $\begin{array}{l}\text { O'Donnell \& } \\
\text { Cigelnik (1997) }\end{array}$ \\
\hline & $\mathrm{Bt} 2 \mathrm{a}$ & $\begin{array}{l}\text { GGTAACCAAATCGGTGC } \\
\text { TGCTTTC }\end{array}$ & Forward & $\begin{array}{l}\text { Glass \& } \\
\text { Donaldson } \\
\text { (1995) }\end{array}$ \\
\hline & $\mathrm{Bt} 2 \mathrm{~b}$ & $\begin{array}{l}\text { ACCCTCAGTGTAGTGACC } \\
\text { CTTGGC }\end{array}$ & Reverse & $\begin{array}{l}\text { Glass \& } \\
\text { Donaldson } \\
(1995)\end{array}$ \\
\hline \multirow{3}{*}{$\begin{array}{l}\text { translation } \\
\text { elongation factor } 1- \\
\text { alpha }(T E F 1-a)\end{array}$} & $\begin{array}{l}\text { EF 1- } \\
728 \mathrm{~F}\end{array}$ & $\begin{array}{l}\text { CAT CGA GAA GTT CGA } \\
\text { GAA GG }\end{array}$ & Forward & $\begin{array}{l}\text { Carbone \& } \\
\text { Kohn (1999) }\end{array}$ \\
\hline & $\begin{array}{l}\text { EF 1- } \\
1567 R\end{array}$ & $\begin{array}{l}\text { ACHGTRCCRATACCACCR } \\
\text { ATCTT }\end{array}$ & Reverse & Rehner (2001) \\
\hline & $\begin{array}{l}\text { EF 1- } \\
2218 R\end{array}$ & $\begin{array}{l}\text { ATGACACCRACRGCRAC } \\
\text { RGTYTG }\end{array}$ & Reverse & Rehner (2001) \\
\hline \multirow[t]{2}{*}{ calmodulin $(C A L)$} & $\begin{array}{l}\text { CAL- } \\
228 \mathrm{~F}\end{array}$ & $\begin{array}{l}\text { GAGTTCAAGGAGGCCTT } \\
\text { CTCCC }\end{array}$ & Forward & $\begin{array}{l}\text { Carbone \& } \\
\text { Kohn (1999) }\end{array}$ \\
\hline & $\begin{array}{l}\text { CAL- } \\
737 R\end{array}$ & $\begin{array}{l}\text { CATCTTTCTGGCCATCAT } \\
\text { GG }\end{array}$ & Reverse & $\begin{array}{l}\text { Carbone \& } \\
\text { Kohn (1999) }\end{array}$ \\
\hline \multirow{2}{*}{$\begin{array}{l}\text { RNA polymerase II } \\
\text { second largest } \\
\text { subunit (RPB2) }\end{array}$} & $\begin{array}{l}\text { fRPB2- } \\
5 \mathrm{~F}\end{array}$ & $\begin{array}{l}\text { GAYGAYMGWGATCAYTT } \\
\text { YGG }\end{array}$ & Forward & Liu et al. (1999) \\
\hline & $\begin{array}{l}\text { fRPB2- } \\
7 \mathrm{cR}\end{array}$ & $\begin{array}{l}\text { CCCATRGCTTGYTTRCCC } \\
\text { AT }\end{array}$ & Reverse & Liu et al. (1999) \\
\hline
\end{tabular}

\section{Results}

\section{Phylogenetic analyses}

Arthrinium. Phylogenetic analysis of Arthrinium was performed on the concatenated dataset of ITS, TUB2 and TEF1-a, with Nigrospora gorlenkoana (CBS 480.73) as outgroup (Fig. 2). The concatenated dataset contained 720 characters with alignment gaps for ITS, 1025 for TUB2, and 602 for TEF1- $a$. The maximum likelihood (ML) tree confirmed the tree topology of the Bayesian consensus (BS) tree. Strains from the newly-collected bee pollen and hive-stored pollen separated into two well-supported clades in the phylogenetic tree of Arthrinium (Fig. 2), which represented one known species, $A$. rasikravindrii, and one novelty described in this study.

Chrysosporium. Phylogenetic analysis of Chrysosporium and related species was performed based on ITS sequences (Fig. 3). Fifty-six sequences from Chrysosporium and Aphanoascus were included in the ITS dataset, with Corynascus sepedonium and Thermothelomyces thermophila as outgroups. The dataset contained 791 characters with alignment gaps. The ML tree confirmed the 
tree topology of BS tree. Strains from the hive-stored pollen formed a distinct clade which closely related to C. submersum and C. hubeiense (Fig. 3).

Nigrograna. Phylogenetic analysis of Nigrograna was performed on the concatenated dataset of LSU, ITS, RPB2 and TEF1-a, with Occultibambusa fusispora (MFLUCC 11-0127) as outgroup (Fig. 4). The concatenated dataset contained 748 characters with alignment gaps for LSU, 439 for ITS, 807 for $R P B 2$, and 691 for TEF1-a. The maximum likelihood (ML) tree confirmed the tree topology of the Bayesian consensus (BS) tree. Strains from the hive-stored pollen formed a distinct and well-supported clade in the 4-locus tree and showed phylogenetic distance from all other species in Nigrograna (Fig. 4).

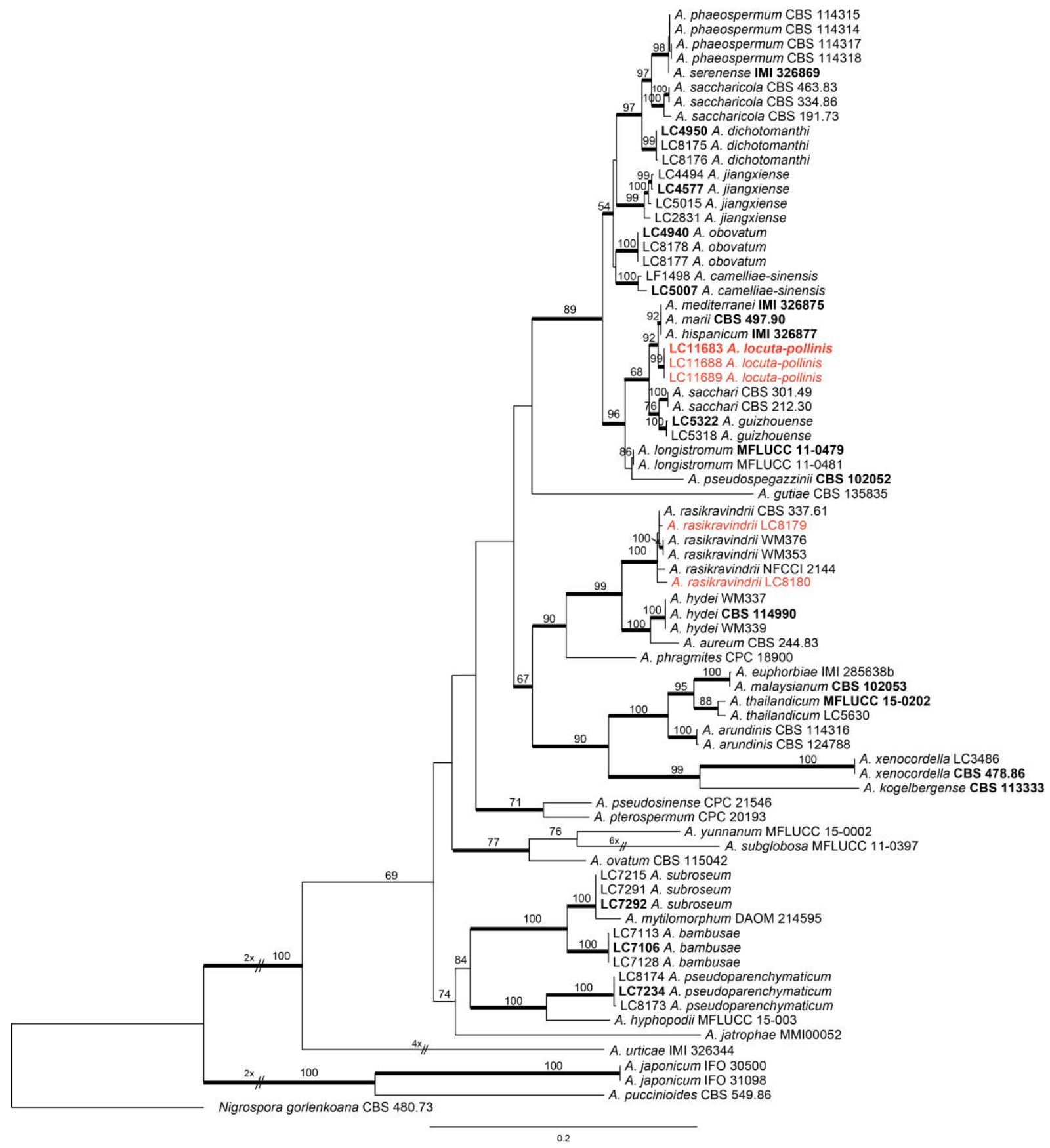

Figure 2 - Phylogenetic tree of Arthrinium calculated with maximum likelihood analysis on a combined dataset of three-locus sequences (ITS, TUB2, TEF1-a) by running RAxML v.7.0.3. The RAxML bootstrap support values (> 50\%) are displayed at the nodes. Thickened branches indicate branches also present in the Bayesian tree with $>0.95$ posterior probabilities. Strains in bold indicate ex-type cultures. Strains obtained in this study are in red colour. 


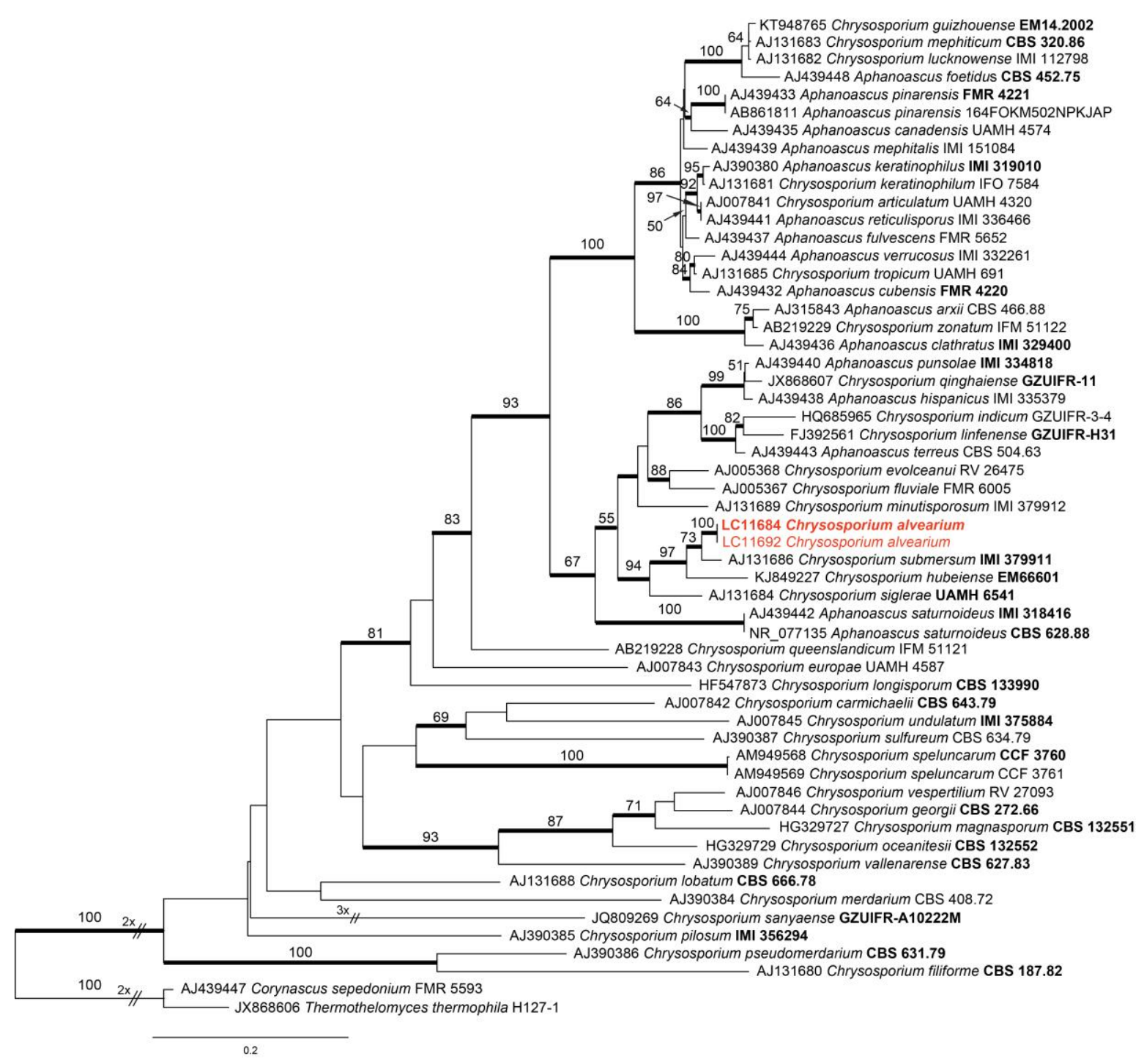

Figure 3 - Phylogenetic tree of Chrysosporium and related taxa calculated with maximum likelihood analysis on ITS sequences by running RAxML v.7.0.3. The RAxML bootstrap support values (> 50\%) are displayed at the nodes. Thickened branches indicate branches also present in the Bayesian tree with $>0.95$ posterior probabilities. Strains in bold indicate ex-type cultures. Strains obtained in this study are in red colour.

Trichoderma. Trichoderma isolates obtained in this study were confirmed belonging to the $T$. harzianum species complex based on the BLASTn searches of the NCBI GenBank nucleotide database and preliminary TEF1- $a$ gene tree (results not shown). Multi-locus phylogenetic analysis of $T$. harzianum species complex was then performed on the concatenated dataset of ITS, RPB2, $A C T, C A L$ and TEF1-a, with T. aggressivum (CBS 100525) as outgroup (Fig. 5). The concatenated dataset contained 535 characters with alignment gaps for ITS, 836 for RPB2, 299 for ACT, 431 for $C A L$ and 597 for TEF1-a. The maximum likelihood (ML) tree confirmed the tree topology of the Bayesian consensus (BS) tree. Strains from the newly-collected pollen formed a distinct and wellsupported clade in the 5-locus tree and showed phylogenetic distance from all other species in $T$. harzianum species complex (Fig. 5).

\section{Taxonomy}

Arthrinium locuta-pollinis F. Liu \& L. Cai, sp. nov.

Fig. 6

MycoBank: MB824505; Facesoffungi number: FoF05221

Etymology - locuta-pollinis, named after the origin of this species, stored pollen. 
Colonies on PDA flat, surface initially white and becoming yellowish in the center, with abundant aerial mycelia, reaching $9 \mathrm{~cm}$ in $7 \mathrm{~d}$ at $25 \mathrm{C}$. On MEA, colonies umbonate, entire edge, surface initially white and becoming yellowish in the center, with abundant aerial mycelia. Hyphae hyaline, or pale brown, branched, septate, $2-5 \mu \mathrm{m}$ diam. Conidiophores reduced to conidiogenous cells. Conidiogenous cells pale brown, smooth, subglobose to ampulliform to doliiform, 3-7.5 $\times 3$ $6 \mu \mathrm{m}$ (av. $\pm \mathrm{SD}=4.9 \pm 1.13 \times 3.8 \pm 0.77 \mu \mathrm{m})$. Conidia pale brown to brown with hyaline equatorial rim, smooth, globose to subglobose, 5.5-9 × 4.5-8 $\mu \mathrm{m}$ (av. $\pm \mathrm{SD}=7.1 \pm 0.55 \times 6.4 \pm 0.66 \mu \mathrm{m})$, or ellipsoidal, $8-15 \times 5-9.5 \mu \mathrm{m}$ (av. $\pm \mathrm{SD}=10.7 \pm 1.47 \times 7.1 \pm 0.85 \mu \mathrm{m}$ ). Elongated cells (sterile cells) formed on solitary loci on hyphae, pale brown or brown, smooth, ellipsoidal to clavate, 11.5$21 \times 3.5-8 \mu \mathrm{m}($ av. $\pm \mathrm{SD}=15.7 \pm 2.22 \times 5.7 \pm 1.08 \mu \mathrm{m})$.

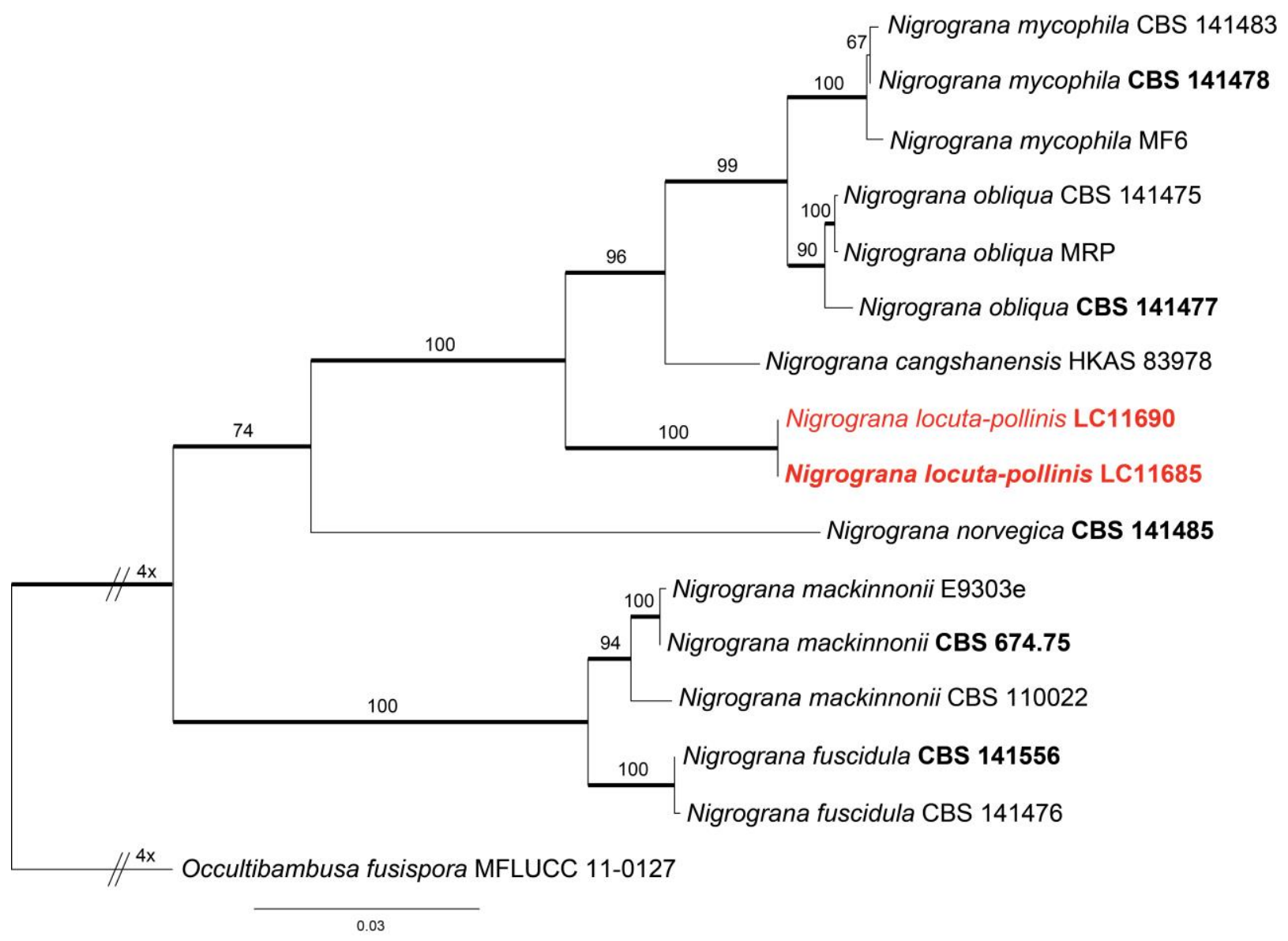

Figure 4 - Phylogenetic tree of Nigrograna calculated with maximum likelihood analysis on a combined dataset of four-locus sequences (ITS, LSU, RPB2, TEF1-a) by running RAxML v.7.0.3. The RAxML bootstrap support values $(>50 \%)$ are displayed at the nodes. Thickened branches indicate branches also present in the Bayesian tree with $>0.95$ posterior probabilities. Strains in bold indicate ex-type cultures. Strains obtained in this study are in red colour.

Materials examined - CHINA, Hubei Province, from hive-stored pollen collected in the Italian honey bee colonies in the flowering season of Brassica campestris, 31 Mar 2016, Y.Z. Zhao (holotype HMAS 247779) - ex-holotype living culture CGMCC 3.18782 = LC 11683 = LF1844; ibid. living cultures LC 11688 = LF2064, LC 11689 = LF2065.

Notes - Arthrinium locuta-pollinis is phylogenetically closely related to A. mediterranei, A. marii and $A$. hispanicum, but differs in distinct morphological characters and nucleotide differences. Arthrinium locuta-pollinis produces globose, subglobose or ellipsoidal conidia, while which are globose or subglobose in A. hispanicum, A. marii and A. mediterranei. Furthermore, A. locuta-pollinis differs from A. mediterranei in producing smaller globose or subglobose conidia $(5.5-9 \times 4.5-8 \mu \mathrm{m}$ vs. $9-9.5 \times 7.5-9 \mu \mathrm{m})$ and longer sterile cells $(11.5-21 \times 3.5-8 \mu \mathrm{m}$ vs. $7-7.5 \times$ 
6.5-7 $\mu \mathrm{m})$ (Larrondo \& Calvo 1992), and differs from A. hispanicum in producing obviously longer sterile cells $(11.5-21 \mu \mathrm{m}$ vs. $<7.5-8.5 \mu \mathrm{m})$ (Larrondo \& Calvo 1992).

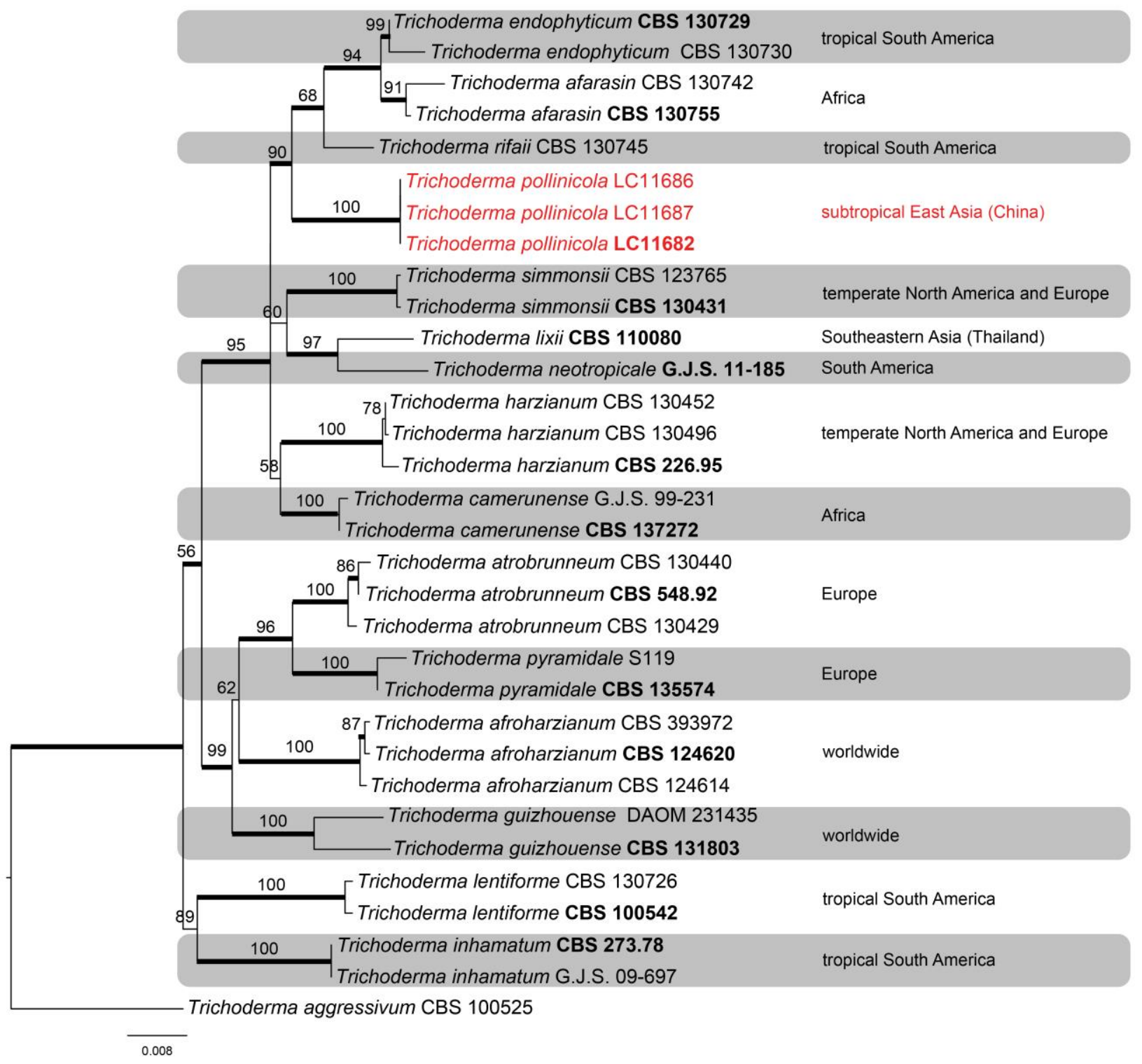

Figure 5 - Phylogenetic tree of Trichoderma harzianum species complex calculated with maximum likelihood analysis on a combined dataset of five-locus sequences (ITS, $A C T, C A L$, $R P B 2, T E F 1-a$ ) by running RAxML v.7.0.3. The RAxML bootstrap support values (> 50\%) are displayed at the nodes. Thickened branches indicate branches also present in the Bayesian tree with $>0.95$ posterior probabilities. Strains in bold indicate ex-type cultures. Strains obtained in this study are in red colour.

Chrysosporium alvearium F. Liu \& L. Cai, sp. nov.

Fig. 7

MycoBank: MB824506; Facesoffungi number: FoF05222

Etymology - alvearium, referring to the place where the fungus was collected, hive.

Description - Colonies on PDA flat or with slightly elevated center, with a daily growth rate of 2-2.5 $\mathrm{mm}$ in the dark at $25 \mathrm{C}$, white coloured, powdery, irregular at the margin; reverse white. Hyphae hyaline, branched, smooth, septate, 1.5-2.5 $\mu \mathrm{m}$ diam. Terminal and lateral conidia sessile or on short or long right-angled side protrusions, solitary or in chains of up to 10 conidia, hyaline, smooth, globose, pyriform, clavate, or obovoid, rarely cylindrical, 1-celled, 4-9 $\times 2-7.5 \mu \mathrm{m}$ (av. \pm $\mathrm{SD}=5.6 \pm 0.8 \times 4.4 \pm 1.1 \mu \mathrm{m})$. Intercalary conidia abundant, solitary or in chains, smooth, 
globose, barrel-shaped, ellipsoid to obvoid, $4-11 \times 3.5-9.5 \mu \mathrm{m}(\mathrm{av} . \pm \mathrm{SD}=7 \pm 1.1 \times 5.9 \pm 1.0 \mu \mathrm{m})$. Racquet hyphae and chlamydospores present. Sexual morph not observed.

Materials examined - CHINA, Hubei Province, from hive-stored pollen collected in the Italian honey bee colonies in the flowering season of Brassica campestris, 31 Mar 2016, Y.Z. Zhao (holotype HMAS 247780) - ex-holotype living culture CGMCC 3.18783 = LC 11684 = LF1882; ibid. living cultures LC 11692 = LF2097, LC 11693 = LF2098.

Notes - Traditionally morphologically defined Chrysosporium is polyphyletic with affiliations to at least three orders of the Ascomycota (Vidal et al. 2000, Pitt et al. 2013). The genus awaits taxonomic revision if the type species $C$. merdarium could be epitypified (Pitt et al. 2013). Morphologically our species is characterized by white colonies and aleurioconidia on undifferentiated hyphae, in agreement to the current morphological circumscription of Chrysosporium (Carmichael 1962). Chrysosporium alvearium is phylogenetically closely related to C. submersum and C. hubeiense (Fig. 3), but their ITS sequences only shows $97 \%$ and $94 \%$ similarities respectively. Morphologically, C. alvearium differs from $C$. submersum by lower growth rate on PDA (28-35 mm/14d vs. 50-60 mm/14d) and the absence of 1-3-septate conidia. In addition, the conidia of $C$. alvearium are commonly in longer chains than that of $C$. submersum (rarely, up to four conidia) (Vidal et al. 2002). In contrast to C. hubeiense, C. alvearium produces longer terminal and lateral conidia $(4-9 \times 2-7.5 \mu \mathrm{m}$ vs. $2.2-4.3 \times 1.6-2.3 \mu \mathrm{m})($ Zhang et al. 2016).

Nigrograna locuta-pollinis F. Liu \& L. Cai, sp. nov.

MycoBank: MB824507; Facesoffungi number: FoF05223

Etymology - locuta-pollinis, named after the origin of this species, stored pollen.

Diagnosis - Growth on PDA after $14 \mathrm{~d}$ at room temperature (ca. $25 \mathrm{C}$ ) flat, entire edge, olivaceous grey, aerial mycelia fluffy, $49 \mathrm{~mm}$ diam.; on MEA flat, entire edge, olivaceous grey, aerial mycelia sparse, $18 \mathrm{~mm}$ diam.; on CMA flat, entire edge, olivaceous to olivaceous black, aerial mycelia sparse, $49 \mathrm{~mm}$ diam. Cultures sterile.

Reference phylogeny - Fig. 4, present study.

Molecular and phylogenetic notes - Nigrograna locuta-pollinis forms a distinct and strongly supported monophyletic clade (ML bootstrap $100 \%$, Bayesian posterior probabilities $=1.00$ ) within genus Nigrograna (Fig. 4). It differs from its closest phylogenetic neighbor, $N$. cangshanensis, by unique fixed alleles in three loci based on alignments of the separate loci demonstrated in the supplementary file (See supplementary file: Fig. S1).

Materials examined - CHINA, Hubei Province, from hive-stored pollen collected in the Italian honey bee colonies in the flowering season of Brassica campestris, 31 Mar 2016, Y.Z. Zhao (holotype HMAS 247781) - ex-holotype living culture CGMCC 3.18784 = LC 11685 = LF1889; ibid. living cultures LC $11690=$ LF2070, LC $11691=$ LF2071.

Notes - Nigrograna was erected by Gruyter et al. (2012), and currently includes five species (Jaklitsch \& Voglmayr 2016). These species were reported from bark of moderately decayed twigs of shrubs and trees and sometimes as human pathogens. They usually produce sexual morph in their life cycle. Nigrograna locuta-pollinis was isolated from hive-stored pollen, expanding the known habitat of this genus, but proved sterile when cultivated on several different media (PDA, $\mathrm{SNA} \pm$ pine needle, CMA, MEA, etc.).

Trichoderma pollinicola F. Liu \& L. Cai, sp. nov.

Fig. 8

MycoBank: MB824508; Facesoffungi number: FoF05224

Etymology - pollinicola, referring to the substrate where the fungus was first discovered, pollen.

Description - Characteristics in culture: Colony radius after $72 \mathrm{~h}$ at $15 \mathrm{C}$ on PDA $8-11 \mathrm{~mm}$, on SNA 9-15 mm, on CMA $17-18 \mathrm{~mm}$; $20 \mathrm{C}$ on PDA $28-30 \mathrm{~mm}$, on SNA 32-34 mm, on CMA 30-31 mm; $25 \mathrm{C}$ on PDA 53-54 mm, on SNA 49-50 mm, on CMA 44-52 mm; at $30 \mathrm{C}$ on PDA 48-49 mm, on SNA $46-49 \mathrm{~mm}$, on CMA $60-65 \mathrm{~mm}$; at $37 \mathrm{C}$ on PDA $12-16 \mathrm{~mm}$, on SNA 7-8 $\mathrm{mm}$, on CMA 8-10 $\mathrm{mm}$. Not growing at $40 \mathrm{C}$. 
On PDA after $96 \mathrm{~h}$ at $25 \mathrm{C}$ aerial hyphae abundant, cottony, radial; conidia appearing within 48-72 h, typically abundant and disposed in three concentric rings around the inoculum. On CMA after $96 \mathrm{~h}$ at $25 \mathrm{C}$ aerial hyphae abundant, cottony, radial; conidia appearing within $48 \mathrm{~h}$, forming abundantly and disposed around the inoculum in the range of $2.5 \mathrm{~cm}$ radius. On SNA after $96 \mathrm{~h}$ at $25 \mathrm{C}$, aerial hyphae sparse, appearing in several concentric rings. Conidia noted within 72-96 h, forming abundantly on aerial hyphae, conidial pustules spreading in concentric rings, $0.5-1.5 \mathrm{~mm}$ in diam. Conidiophores pyramidal, comprising a distant main axis, side branches paired or unpaired, often at acute angles with the main axis, re-branching up to 3 levels. Phialides solitary or in whorls of 2-4, lageniform to ampulliform, 4.5-9.5 $\times 2.5-4 \mu \mathrm{m}$ (av. $\pm \mathrm{SD}=6.7 \pm 1.2 \times 3.0 \pm 0.2$ $\mu \mathrm{m})$, length/width ratio $=2.2$, base $1.5-2.5 \mu \mathrm{m}$ wide $(\mathrm{av} .=2 \mu \mathrm{m})$, supporting cells $2-4 \mu \mathrm{m}$ wide $(\mathrm{av} .=3.1 \mu \mathrm{m})$. Conidia globose or subglobose, rarely ovoid, $2.5-3.5 \times 2-3 \mu \mathrm{m}(\mathrm{av} . \pm \mathrm{SD}=2.8 \pm$ $0.1 \times 2.6 \pm 0.1 \mu \mathrm{m})$, length/ width ratio $=1.1$, smooth, green. Chlamydospores not observed.

Materials examined - CHINA, Hubei Province, from newly-collected pollen collected in the Italian honey bee colonies in the flowering season of Brassica campestris, 31 Mar 2016, Y.Z. Zhao (holotype HMAS 247782) - ex-holotype living culture CGMCC 3.18781 = LC 11682 = LF1542; ibid. living cultures LC $11686=$ LF2050, LC $11687=$ LF2051.

Notes - Strains of Trichoderma pollinicola formed a well-supported and distinct clade in the T. harzianum species complex based on multi-locus (ITS, ACT, CAL, TEF1-a, RPB2) phylogenetic analysis (Fig. 5). It differs from the phylogenetically related species $T$. rifaii in lower growth rate (e.g. colony radius after $72 \mathrm{~h}$ at $25^{\circ} \mathrm{C}$ on PDA 53-54 mm vs. 62-67 mm, on SNA 49-50 mm vs. 55-65mm) (Chaverri et al. 2015). Trichoderma pollinicola is similar to T. rifaii in microstructure, but they can be distinguished from each other either by RPB2 (96\% similarity, 32 bp differences) or TEF1-a (96\% similarity, 21 bp differences) sequence data.
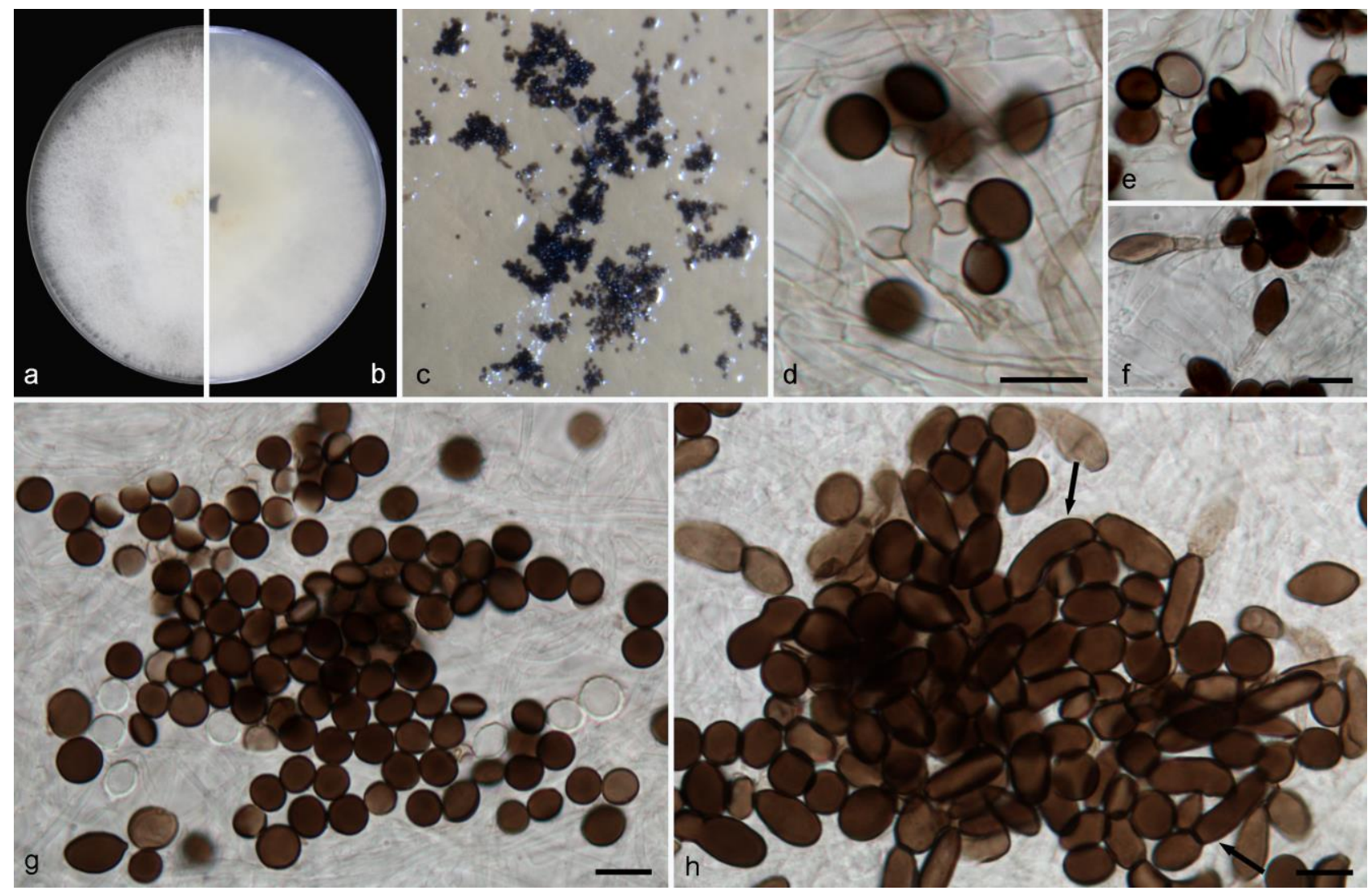

Figure 6 - Arthrinium locuta-pollinis (ex-holotype CGMCC 3.18782 = LC 11683). a-b Colonies after $7 \mathrm{~d}$ on PDA. c. Colony on MEA producing conidia mass. $\mathrm{d}-\mathrm{f}$ Conidiogenous cells giving rise to conidia. g Conidia. h Conidia and elongated conidia (might be sterile cells, indicated by arrows). Bar $=10 \mu \mathrm{m}$. 


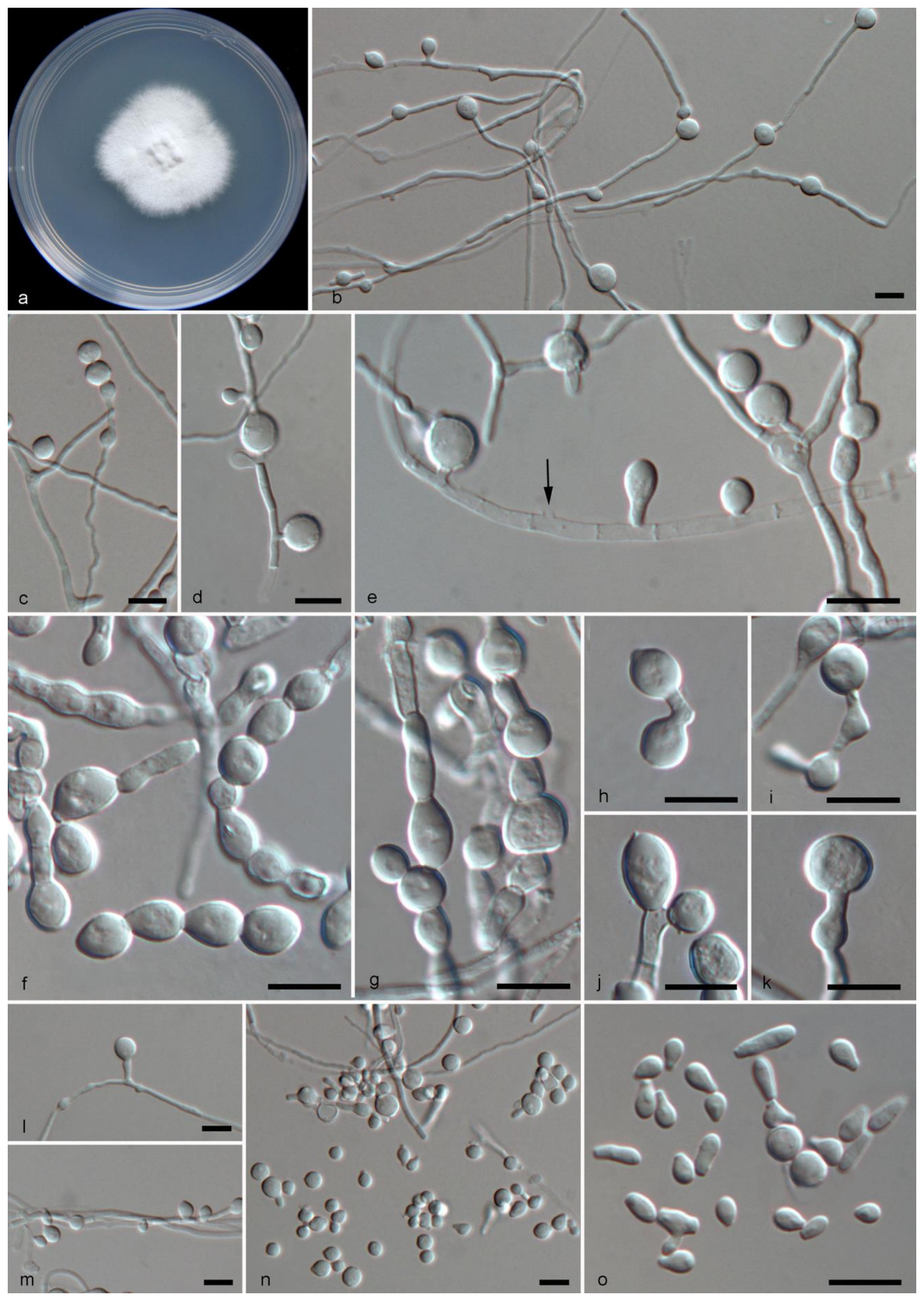

Figure 7 - Chrysosporium alvearium (ex-holotype CGMCC $3.18783=$ LC 11684). a Colony after $10 \mathrm{~d}$ on PDA. $\mathrm{b}-\mathrm{e}, \mathrm{h}-\mathrm{m}$ Conidiogenous structures. $\mathrm{f}-\mathrm{g}$ Conidia in chains. $\mathrm{n}-\mathrm{o}$ Conidia. Scale Bar $=$ $10 \mu \mathrm{m}$. 


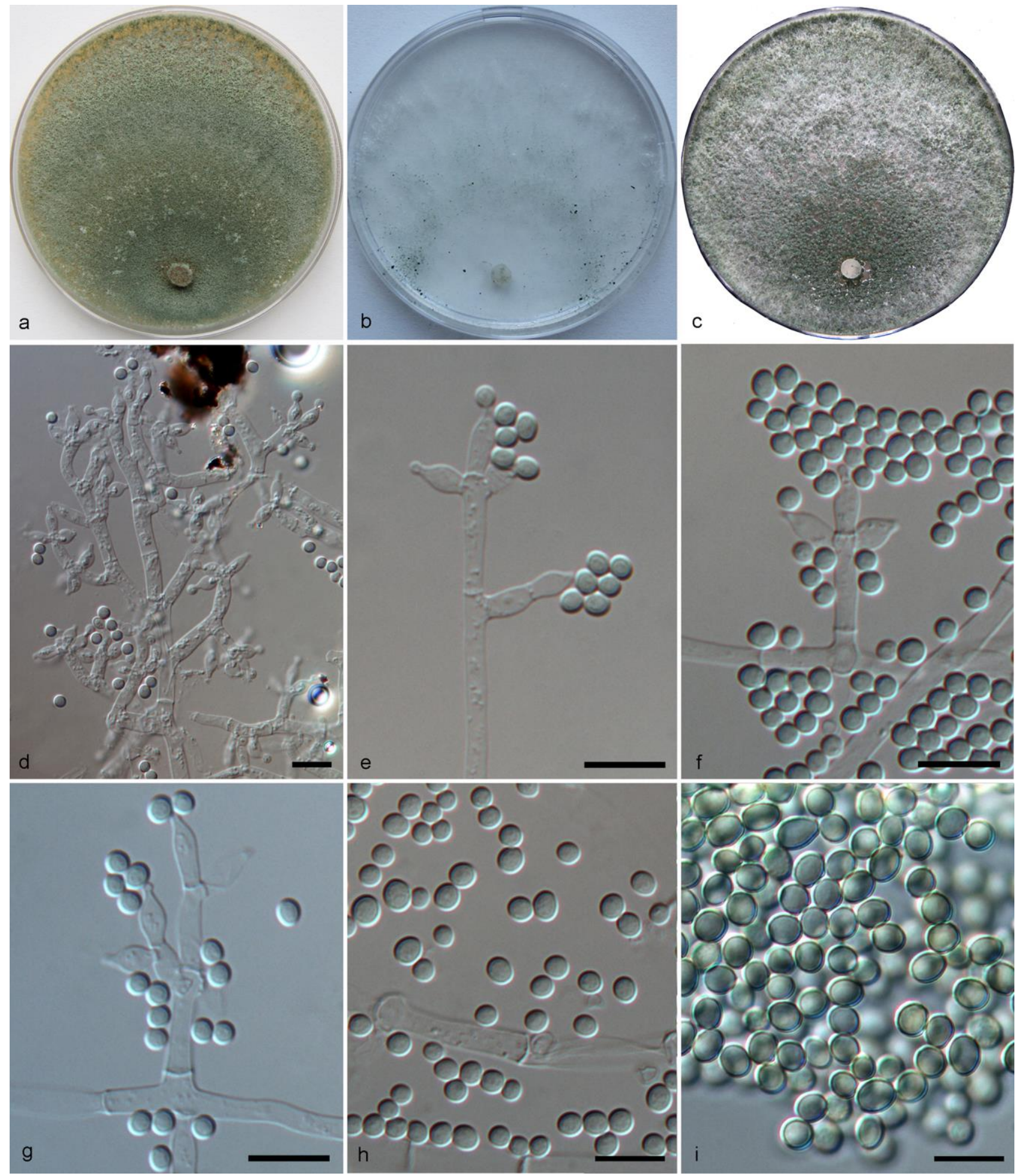

Figure 8 - Trichoderma pollinicola (ex-holotype CGMCC 3.18781 = LC 11682). a-c Colonies after $7 \mathrm{~d}$ at $25{ }^{\circ} \mathrm{C}$ (a. PDA. b. SNA. c. CMA). d Conidiophores. e-g Phialides. h. Hyaline to light green conidia when young. i Green conidia with age. Scale Bar $=10 \mu \mathrm{m}$.

\section{Discussion}

During our survey of culturable fungi from newly-collected and hive-stored pollen, four new species were identified, i.e. Arthrinium locuta-pollinis, Chrysosporium alvearium, Nigrograna locuta-pollinis and Trichoderma pollinicola. As far as we know, nine previously described Chrysosporium species were recorded from mason bees (Osmia spp.), beehives, bee pollen and honey, i.e. C. botryoides, $C$. farinicola, $C$. globiferum and its two varieties, $C$. hispanicum, $C$. holmii, $C$. medium, $C$. merdarium and its variety, $C$. minor and $C$. pyriforme. Most of above species 
representing extreme xerophiles have already been combined into Xerochrysium or Bettsia except C. merdarium (Pitt et al. 2013). Although C. alvearium was isolated from hive-stored pollen from beehives and the genus Chrysosporium is polyphyletic, it shows very low similarity to Xerochrysium or Bettsia.

Species in the $T$. harzianum complex were recently indicated having a tendency of specialization for habitat (Chaverri et al. 2015). Some were demonstrated to be endophytic, while others were only isolated from soil. In the present study, T. pollinicola was isolated from the newly-collected pollen of Brassica campestris, however we could not determine whether $T$. pollinicola was the endophyte of $B$. campestris or environment related fungus. It is worth noting that, we did not obtain any Trichoderma strain when performing fungal isolation from the flowers of B. campestris at the same time (results not shown). As far as we know, only one species in Trichoderma, T. pseudokoningii, was previously recorded from B. campestris from Canada (Rifai 1969), while which belongs to Longibrachiatum clade (Jaklitsch \& Voglmayr 2015).

Arthrinium species are geographically distributed in various substrates, e.g. host plants, air and soil (Wang et al. 2018). Arthrinium camelliae-sinensis has recently been reported from pollen product of Brassica campestris ('Huaxing' brand) which made from fresh-collected pollen (Wang et al. 2018). Whereas in the present study, A. locuta-pollinis is isolated from hive-stored pollen of Brassica campestris, but not from newly-collected pollen. It is probably that A. locuta-pollinis was introduced through bees' activity or from air. According to the multi-locus phylogeny (Fig. 2), A. mediterranei, A. marii and A. hispanicum showed phylogenetic identity. Further comparison revealed that ITS and TUB2 sequences of type strains of above three species are identical, and the $T E F$ sequences of $A$. mediterranei and $A$. hispanicum are absent in any public database for comparison. Further researches are therefore required to determine their conspecific or heterogeneity.

Culture media such as YPD and MRS are commonly used for bacteria and yeast isolation. Surprisingly we obtained some exclusive species comparing to the most commonly used PDA medium (results not shown), for example, the two new species A. locuta-pollinis and C. alvearium were only isolated from YPD, and T. pollinicola was only from MRS. While $N$. locuta-pollinis was only isolated on PDA. The exclusive fungi obtained from YPD and MRS may be more in favor of the yeast/bacterial dominated environment. Another possibility is that, when the diluted concentration of pollen is low enough, the growth space of A. locuta-pollinis, C. alvearium and T. pollinicola were not be occupied and restrained by favorable yeast or bacteria on YPD and MRS. Above results demonstrated that the application of different culture media and dilution concentration of materials could help to reveal more microbial biodiversity.

\section{Acknowledgements}

This study was financially supported by the Agricultural Science and Technology Innovation Program, China (ASTIP). Xiaohong Chen is thanked for help with partial fungal isolation and PCR amplification, and Kai Chen is thanked for assistance on phylogenetic analysis of genus Trichoderma. We also acknowledge Shengming Han for providing pictures of sampling sites in Fig. 1.

\section{References}

Almaraz-Abarca N, Campos MDG, Ávila-Reyes JA, Naranjo-Jiménez N et al. 2004 - Variability of antioxidant activity among honeybee-collected pollen of different botanical origin 29(10), 574-578.

Brovarskyi V, Velychko S, Brindza J, Adamchuk L. 2017 - Development and testing of the technology of production of the beebread with the use of artificial combs. Agrobiodiversity for Improving Nutrition, Health and Life Quality 1, 31-42.

Carbone I, Kohn LM. 1999 - A method for designing primer sets for speciation studies in filamentous ascomycetes. Mycologia 91, 553-556. 
Carmichael JW. 1962 - Chrysosporium and some other aleuriosporic hyphomycetes. Canadian Journal of Botany 40(8), 1137-1173.

Chaverri P, Branco-Rocha F, Jaklitsch W, Gazis R et al. 2015 - Systematics of the Trichoderma harzianum species complex and the re-identification of commercial biocontrol strains. Mycologia 107(3), 558-590.

Egorova A1. 1971 - Preservative microflora in stored pollen. Veterinariya 8, 40-41.

Foote HL. 1957 - Possible use of microorganisms in synthetic bee bread production. The American Bee Journal 97, 476-478.

Gao Y, Liu F, Duan W, Crous PW, Cai L. 2017 - Diaporthe is paraphyletic. IMA Fungus 8(1), $153-187$.

Giesecke T, Fontana SL, van der Knaap WO, Pardoe HS, Pidek IA. 2010 - From early pollen trapping experiments to the Pollen Monitoring Programme. Vegetation History and Archaeobotany 19(4), 247-258.

Gilliam M. 1979 - Microbiology of pollen and bee bread: the yeasts. Apidologie 10, 43-53.

Gilliam M, Prest DB, Lorenz BJ. 1989 - Microbiology of pollen and bee bread: taxonomy and enzymology of molds. Apidologie 20(1), 53-68.

Glass NL, Donaldson G. 1995 - Development of primer sets designed for use with PCR to amplify conserved genes from filamentous ascomycetes. Applied and Environmental Microbiology $61,1323-1330$.

Gruyter J de, Woudenberg JHC, Aveskamp MM, Verkley GJ et al. 2012 - Redisposition of Phomalike anamorphs in Pleosporales. Studies in Mycology 75, 1-36.

Guo LD, Hyde KD, Liew ECY. 2000 - Identification of endophytic fungi from Livistona chinensis based on morphology and rDNA sequences. New Phytologist 147, 617-630.

Haydak MH. 1958 - Pollen-pollen substitutes-beebread. The American Bee Journal 98, 145-146.

Jaklitsch WM, Voglmayr H. 2015 - Biodiversity of Trichoderma (Hypocreaceae) in Southern Europe and Macaronesia. Studies in Mycology 80, 1-87.

Jaklitsch WM, Voglmayr H. 2016 - Hidden diversity in Thyridaria and a new circumscription of the Thyridariaceae. Studies in Mycology 85, 35-64.

Kieliszek M, Piwowarek K, Kot AM, Blazejak S et al. 2018 - Pollen and bee bread as new healthoriented products: A review. Trends in Food Science \& Technology 71, 170-180.

Kroyer G, Hegedus N. 2001 - Evaluation of bioactive properties of pollen extracts as functional dietary food supplement. Innovative Food Science \& Emerging Technologies 2(3), 171-174.

Larrondo JV, Calvo MA. 1992 - New contributions to the study of the genus Arthrinium. Mycologia 84(3), 475-478.

Liu YJ, Whelen S, Hall BD. 1999 - Phylogenetic relationships among ascomycetes: evidence from an RNA Polymerase II subunit. Molecular Biology and Evolution 16, 1799-1808.

Liu F, Cai L, Crous PW, Damm U. 2014 - The Colletotrichum gigasporum species complex. Persoonia 33, 83-97.

O’Donnell K, Cigelnik E. 1997 - Two divergent intragenomic rDNA ITS2 types within a monophyletic lineage of the fungus Fusarium are nonorthologous. Molecular Phylogenetics and Evolution 7, 103-116.

Pitt JI, Lantz H, Pettersson OV, Leong SL. 2013 - Xerochrysium gen. nov. and Bettsia, genera encompassing xerophilic species of Chrysosporium. IMA Fungus 4(2), 229-241.

Rehner SA. $2001-$ Primers for Elongation Factor 1-alpha (EF1-alpha). http://ocid.nacse.org/research/deephyphae/EF1 primer.pdf (accessed 13.02.01)

Rehner SA, Samuels GJ. 1994 - Taxonomy and phylogeny of Gliocladium analyzed from nuclear large subunit ribosomal DNA sequences. Mycological Research 98, 625-634.

Rifai MA. 1969 - A revision of the genus Trichoderma. Mycological Papers 116, 1-56.

Ronquist F, Teslenko M, van der Mark P, Ayres DL et al. 2012 - MrBayes 3.2: efficient Bayesian phylogenetic inference and model choice across a large model space. Systermatic Biology 61(3), 539-542. 
Sainger JK, Garg AP, Sharma PD. 1978 - Mycoflora of some pollen grains. Acta Botanica Brasilica 6, 165-168.

Smith H, Wingfield MJ, Crous PW, Coutinho TA. 1996 - Sphaeropsis sapinea and Botryosphaeria dothidea endophytic in Pinus spp. and Eucalyptus spp. in South Africa. South African Journal of Botany 62, 86-88.

Stamatakis A. 2006 - RAxML-VI-HPC: Maximum Likelihood-based phylogenetic analyses with thousands of taxa and mixed models. Bioinformatics 22(21), 2688-2690.

Vidal P, Valmaseda M, Vinuesa MA, Guarro J. 2002 - Two new species of Chrysosporium. Studies in Mycology (47), 199-209.

Vidal P, Vinuesa MA, Sánchez-Puelles JM, Guarro J. 2000 - Phylogeny of the anamorphic genus Chrysosporium and related taxa based on rDNA internal transcribed spacer sequences. Revista Iberoamericana de Micología 17, 22-29.

Wang M, Tan XM, Liu F, Cai L. 2018 - Eight new Arthrinium species from China. MycoKeys 34, $1-24$.

White TJ, Bruns T, Lee S, Taylor J. 1990 - Amplification and direct sequencing of fungal ribosomal RNA genes for phylogenetics. In: Innis MA, Gelfand DH, Sninsky JJ, White TJ, eds. PCR protocols: A guide to methods and applications. New York, NY: Academic Press. p. 315-322.

Zhang Y, Liu F, Wu W, Cai L. 2015 - A phylogenetic assessment and taxonomic revision of the thermotolerant hyphomycete genera Acrophialophora and Taifanglania. Mycologia 107, $768-779$.

Zhang YW, Chen WH, Zeng GP, Wang YR et al. 2016 - Two new Chrysosporium (Onygenaceae, Onygenales) from China. Phytotaxa 270(3), 210-216. 


\section{Supplementary files:}

LSU:

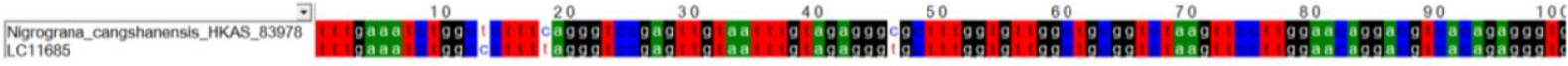

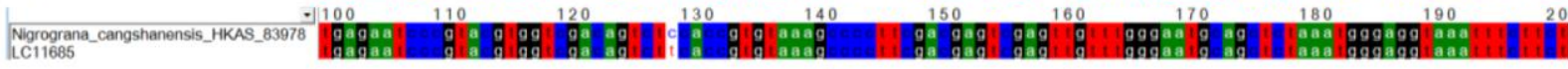

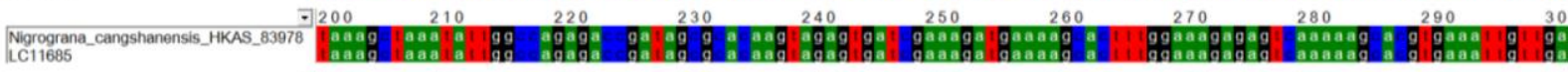

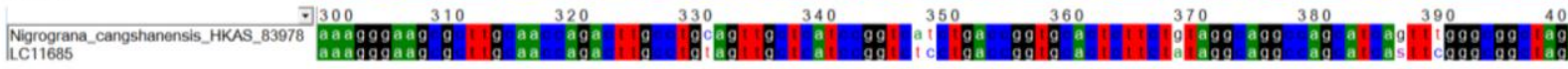

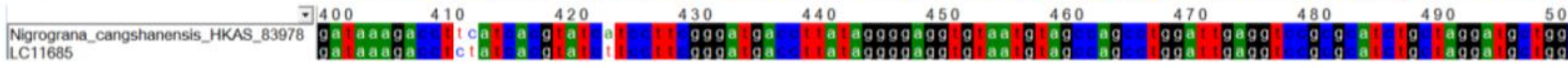

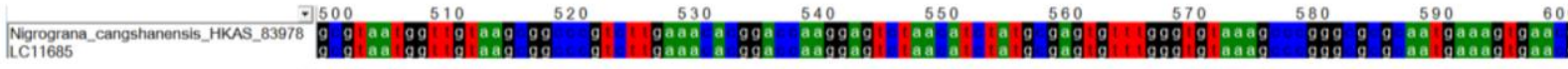

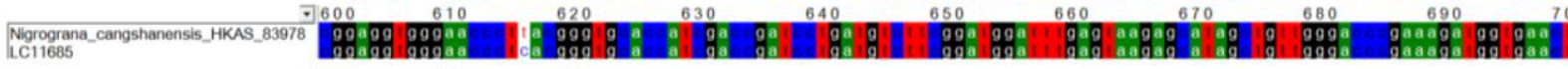

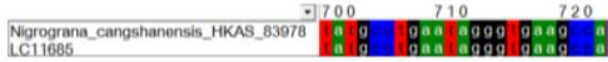

\section{ITS:}

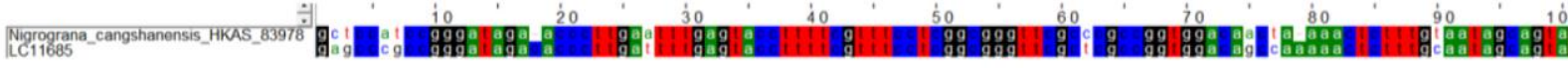

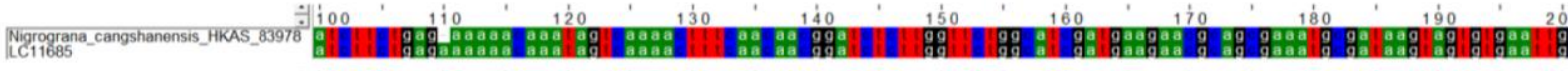

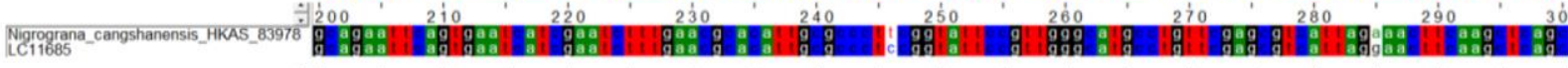

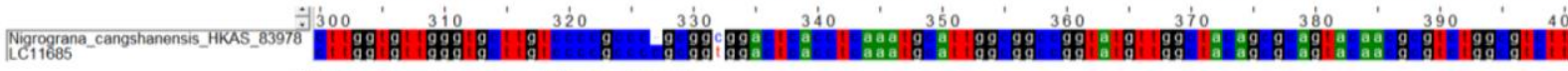

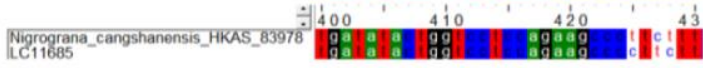

TEF1-a:

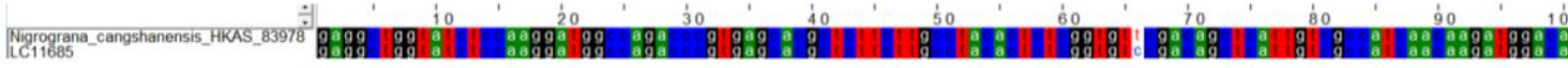

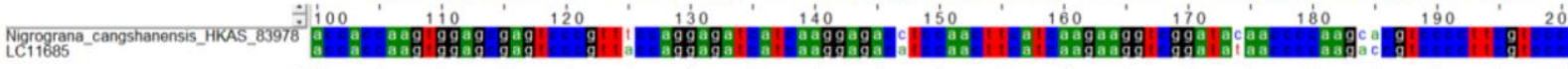

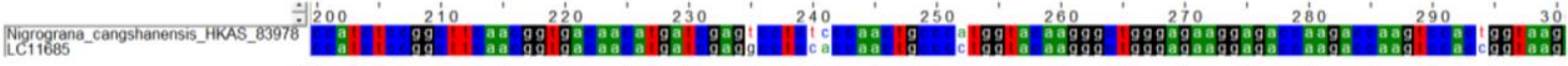

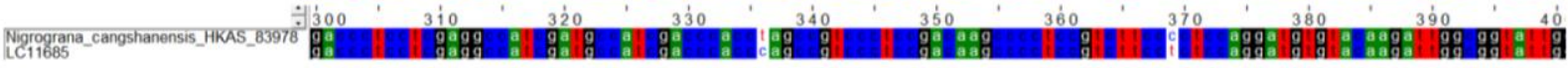

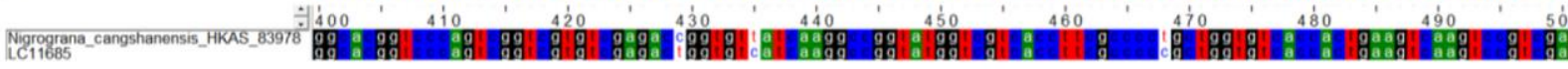

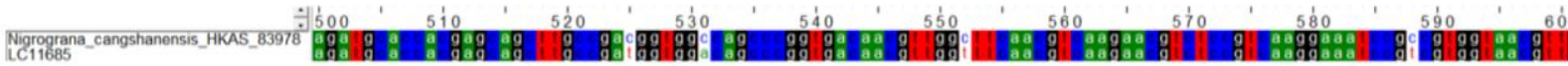

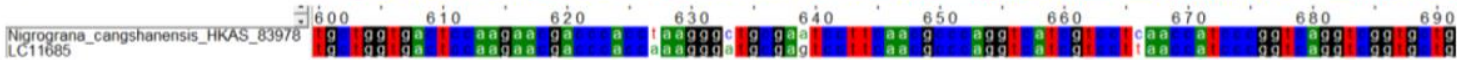

Figure S1 - Sequence alignments of Nigrograna locuta-pollinis and N. cangshanensis 
Table S1 Strains used in this study.

\begin{tabular}{|c|c|c|c|c|c|c|c|c|c|c|}
\hline \multirow{2}{*}{ Figs } & \multirow{2}{*}{ Species } & \multirow{2}{*}{ Strain number ${ }^{1}$} & \multirow{2}{*}{ Host } & \multicolumn{7}{|c|}{ GenBank accessions $^{2}$} \\
\hline & & & & ITS & TUB & TEF & RPB2 & $28 \mathrm{~S}$ & ACT & CAL \\
\hline \multirow{28}{*}{ Fig. 2} & \multirow{4}{*}{$\begin{array}{l}\text { Arthrinium } \\
\text { arundinis }\end{array}$} & \multirow{2}{*}{ CBS 114316} & \multirow{2}{*}{ Leaf of Hordeum vulgare } & KF1448 & KF1449 & KF1450 & & & & \\
\hline & & & & 84 & 74 & 16 & & & & \\
\hline & & \multirow{2}{*}{ CBS 124788} & \multirow{2}{*}{$\begin{array}{l}\text { Living leaves of Fagus } \\
\text { sylvatica }\end{array}$} & KF1448 & KF1449 & KF1450 & & & & \\
\hline & & & & 85 & 75 & 17 & & & & \\
\hline & \multirow{2}{*}{ A. aureum } & \multirow{2}{*}{ CBS 244.83* } & \multirow{2}{*}{ Air } & AB2202 & KF1449 & KF1450 & & & & \\
\hline & & & & 51 & 81 & 23 & & & & \\
\hline & \multirow[t]{5}{*}{ A. bambusae } & $\begin{array}{l}\text { LC7106 = } \\
\text { WM340 }\end{array}$ & \multirow[t]{2}{*}{ Leaf of bamboo } & KY4947 & KY7051 & KY8062 & & & & \\
\hline & & WIM340 & & 18 & 86 & 04 & & & & \\
\hline & & LC $7113=$ & \multirow{2}{*}{ Leaf of bamboo } & KY4947 & KY7051 & KY8062 & & & & \\
\hline & & I C7128 - & & & 88 & & & & & \\
\hline & & WM362 & Leaf of bamboo & KY4947 & KY7051 & KY7051 & & & & \\
\hline & \multirow{4}{*}{$\begin{array}{l}\text { A. camelliae- } \\
\text { sinensis }\end{array}$} & & \multirow{2}{*}{ Camellia sinensis } & KY4947 & KY7051 & KY7051 & & & & \\
\hline & & LC5007 & & 04 & 73 & 03 & & & & \\
\hline & & LC8181 = & \multirow{2}{*}{ Brassica capestris } & KY4947 & KY7052 & KY7051 & & & & \\
\hline & & LF1498 & & 61 & 29 & 57 & & & & \\
\hline & \multirow{6}{*}{ A. dichotomanthi } & \multirow{2}{*}{ LC4950 } & Dichotomanthus & KY4946 & KY7051 & KY7050 & & & & \\
\hline & & & tristaniaecarpa & 97 & 67 & 96 & & & & \\
\hline & & \multirow{2}{*}{ LC8175 } & Dichotomanthus & KY4947 & KY7052 & KY7051 & & & & \\
\hline & & & tristaniaecarpa & 55 & 23 & 51 & & & & \\
\hline & & \multirow{2}{*}{ LC8176 } & Dichotomanthus & KY4947 & KY7052 & KY7051 & & & & \\
\hline & & & tristaniaecarpa & 56 & 24 & 52 & & & & \\
\hline & A. euphorbiae & IMI 285638b & Unknown & AB2202 & AB2202 & - & & & & \\
\hline & \multirow{3}{*}{ A. guizhouense } & \multirow[b]{2}{*}{ LC5318 } & \multirow[b]{2}{*}{ Air } & $\begin{array}{l}41 \\
\text { KY4947 }\end{array}$ & $\begin{array}{l}\text { Oo } \\
\text { KY7051 }\end{array}$ & KY7051 & & & & \\
\hline & & & & 08 & 77 & & & & & \\
\hline & & LC5322 & Air & $\begin{array}{l}\text { KY4947 } \\
09\end{array}$ & $\begin{array}{l}\text { KY7051 } \\
78\end{array}$ & $\begin{array}{l}\text { KY7051 } \\
08\end{array}$ & & & & \\
\hline & \multirow{2}{*}{ A. gutiae } & CBS 135835 & & KR0113 & KR0113 & KR0113 & & & & \\
\hline & & CBS 135835 & Gut of a grasshopper & & 50 & 51 & & & & \\
\hline & A. hispanicum & IMI 326877* & Maritime sand & $\begin{array}{l}\mathrm{AB} 2202 \\
42\end{array}$ & $\begin{array}{l}\text { AB2202 } \\
89\end{array}$ & - & & & & \\
\hline
\end{tabular}


Table S1 Continued.

\begin{tabular}{|c|c|c|c|c|c|c|c|c|c|c|}
\hline \multirow{2}{*}{ Figs } & \multirow{2}{*}{ Species } & \multirow{2}{*}{ Strain number ${ }^{1}$} & \multirow{2}{*}{ Host } & \multicolumn{7}{|c|}{ GenBank accessions $^{2}$} \\
\hline & & & & ITS & TUB & TEF & RPB2 & $28 \mathrm{~S}$ & ACT & CAL \\
\hline & \multirow[t]{5}{*}{ A. hydei } & CBS 114990* & Culms of Bambusa tuldoides & KF1448 & KF1449 & KF1450 & & & & \\
\hline & & \multirow{4}{*}{$\begin{array}{l}\text { LC7103 = } \\
\text { WM337 } \\
\text { LC7105 = } \\
\text { WM339 }\end{array}$} & \multirow{2}{*}{ Leaf of bamboo } & KY4947 & $\begin{array}{l}\text { K2 } \\
\text { KY7051 }\end{array}$ & $\begin{array}{l}24 \\
\text { KY7051 }\end{array}$ & & & & \\
\hline & & & & 15 & 83 & 14 & & & & \\
\hline & & & \multirow{2}{*}{ Leaf of bamboo } & KY4947 & KY7051 & KY7051 & & & & \\
\hline & & & & 17 & 85 & 16 & & & & \\
\hline & A. hyphopodii & $\begin{array}{l}\text { MFLUCC 15- } \\
0003 *\end{array}$ & Culms of Bambusa tuldoides & $\begin{array}{l}\text { KR0691 } \\
10\end{array}$ & - & - & & & & \\
\hline & \multirow[t]{2}{*}{ A. japonicum } & IFO 30500 & Unknown & $\begin{array}{l}\text { AB2202 } \\
62\end{array}$ & $\begin{array}{l}\text { AB2203 } \\
09\end{array}$ & - & & & & \\
\hline & & IFO 31098 & Unknown & $\begin{array}{l}\mathrm{AB} 2202 \\
64\end{array}$ & AB2203 & - & & & & \\
\hline & A. jatrophae & MMI00052* & $\begin{array}{l}\text { Healthy petiole of Jatropha } \\
\text { podagrica }\end{array}$ & $\begin{array}{l}\text { JQ2463 } \\
55\end{array}$ & 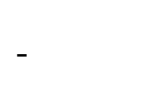 & - & & & & \\
\hline & \multirow{7}{*}{ A. jiangxiense } & \multirow{2}{*}{ LC2831 } & \multirow{2}{*}{ Leaf of bamboo } & KY4946 & KY8062 & KY7050 & & & & \\
\hline & & & & 86 & 01 & 85 & & & & \\
\hline & & \multirow{2}{*}{ LC4494 } & \multirow{2}{*}{ Phyllostachys sp. } & KY4946 & KY7051 & KY7050 & & & & \\
\hline & & & & 90 & 60 & 89 & & & & \\
\hline & & \multirow[t]{2}{*}{ LC4577 } & \multirow[t]{2}{*}{ Maesa sp. } & KY4946 & KY7051 & KY7050 & & & & \\
\hline & & & & 93 & 63 & 92 & & & & \\
\hline & & LC5015 & Imperata cylindrica & KY4947 & KY7051 & KY7051 & & & & \\
\hline & \multirow{2}{*}{ A. kogelbergense } & \multirow{2}{*}{ CBS $113333^{*}$} & \multirow{2}{*}{ Dead culms of Restionaceae } & KF1448 & KF1449 & $\begin{array}{l}04 \\
\text { KF1450 }\end{array}$ & & & & \\
\hline & & & & 92 & 84 & 26 & & & & \\
\hline & \multirow{6}{*}{$\begin{array}{l}\text { A. locuta- } \\
\text { pollinis }\end{array}$} & \multirow{7}{*}{$\begin{array}{l}\text { LC11683 = } \\
\text { LF1844* } \\
\text { LC11688 = } \\
\text { LF2064 } \\
\text { LC11689 = } \\
\text { LF2065 } \\
\text { MFLUCC 11- } \\
\text { 0481* }\end{array}$} & \multirow{6}{*}{$\begin{array}{l}\text { Hive-stored pollen of } \\
\text { Brassica campestris } \\
\text { Hive-stored pollen of } B . \\
\text { campestris } \\
\text { Hive-stored pollen of } B . \\
\text { campestris }\end{array}$} & MF9395 & MF9396 & MF9396 & & & & \\
\hline & & & & & & & & & & \\
\hline & & & & MF9395 & MF9396 & MF9396 & & & & \\
\hline & & & & 97 & 23 & 18 & & & & \\
\hline & & & & MF9395 & MF9396 & MF9396 & & & & \\
\hline & & & & & 24 & 17 & & & & \\
\hline & A. longistromum & & Decaying bamboo culms & $\begin{array}{l}\text { KU9401 } \\
41\end{array}$ & - & - & & & & \\
\hline
\end{tabular}


Table S1 Continued.

\begin{tabular}{|c|c|c|c|c|c|c|c|c|c|c|}
\hline \multirow{2}{*}{ Figs } & \multirow{2}{*}{ Species } & \multirow{2}{*}{ Strain number ${ }^{1}$} & \multirow{2}{*}{ Host } & \multicolumn{7}{|c|}{ GenBank accessions $^{2}$} \\
\hline & & & & ITS & TUB & TEF & RPB2 & $28 S$ & ACT & CAL \\
\hline & & $\begin{array}{l}\text { MFLUCC 11- } \\
0479\end{array}$ & Decaying bamboo culms & $\begin{array}{l}\text { KU9401 } \\
42\end{array}$ & - & - & & & & \\
\hline & A. malaysianum & CBS $102053^{*}$ & $\begin{array}{l}\text { Macaranga hullettii stem } \\
\text { colonised by ants }\end{array}$ & $\begin{array}{l}\text { KF1448 } \\
96\end{array}$ & $\begin{array}{l}\text { KF1449 } \\
88\end{array}$ & $\begin{array}{l}\text { KF1450 } \\
30\end{array}$ & & & & \\
\hline & A. marii & CBS 497.90* & 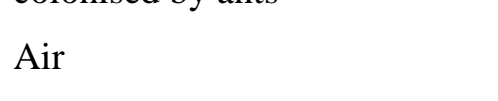 & $\begin{array}{l}\mathrm{AB} 2202 \\
52\end{array}$ & $\begin{array}{l}\text { KF1449 } \\
93\end{array}$ & $\begin{array}{l}\mathrm{KF} 1450 \\
35\end{array}$ & & & & \\
\hline & A. mediterranei & IMI $326875^{*}$ & Air & $\begin{array}{l}\mathrm{AB} 2202 \\
43\end{array}$ & $\begin{array}{l}\text { AB2202 } \\
90\end{array}$ & $=0$ & & & & \\
\hline & $\begin{array}{l}\text { A. } \\
\text { mytilomorphum }\end{array}$ & DAOM 214595 & Dead blades of Andropogon & $\begin{array}{l}\text { KY4946 } \\
85\end{array}$ & 然 & - & & & & \\
\hline & A. obovatum & LC4940 & Lithocarpus sp. & $\begin{array}{l}\text { KY4946 } \\
96\end{array}$ & $\begin{array}{l}\text { KY7051 } \\
66\end{array}$ & $\begin{array}{l}\text { KY7050 } \\
95\end{array}$ & & & & \\
\hline & & LC8178 & Lithocarpus sp. & $\begin{array}{l}\text { KY } 4947 \\
58\end{array}$ & $\begin{array}{l}\text { KY7052 } \\
26\end{array}$ & $\begin{array}{l}\text { KY7051 } \\
54\end{array}$ & & & & \\
\hline & & LC8177 & Lithocarpus sp. & $\begin{array}{l}\text { KY4947 } \\
57\end{array}$ & $\begin{array}{l}\text { KY7052 } \\
25\end{array}$ & $\begin{array}{l}\text { KY7051 } \\
53\end{array}$ & & & & \\
\hline & A. ovatum & CBS $115042^{*}$ & Arundinaria hindsii & $\begin{array}{l}\text { KF } 1449 \\
03\end{array}$ & $\begin{array}{l}\text { KF1449 } \\
95\end{array}$ & $\begin{array}{l}\mathrm{KF} 1450 \\
37\end{array}$ & & & & \\
\hline & $\begin{array}{l}\text { A. } \\
\text { phaeospermum }\end{array}$ & CBS 114314 & Leaf of Hordeum vulgare & $\begin{array}{l}\text { KF } 1449 \\
04\end{array}$ & $\begin{array}{l}\text { KF1449 } \\
96\end{array}$ & $\begin{array}{l}\mathrm{KF} 1450 \\
38\end{array}$ & & & & \\
\hline & & CBS 114315 & Leaf of Hordeum vulgare & $\begin{array}{l}\text { KF1449 } \\
05\end{array}$ & $\begin{array}{l}\text { KF1449 } \\
97\end{array}$ & $\begin{array}{l}\text { KF1450 } \\
39\end{array}$ & & & & \\
\hline & & CBS 114317 & Leaf of Hordeum vulgare & $\begin{array}{l}\text { KF } 1449 \\
06\end{array}$ & $\begin{array}{l}\text { KF1449 } \\
98\end{array}$ & $\begin{array}{l}\mathrm{KF} 1450 \\
40\end{array}$ & & & & \\
\hline & & CBS 114318 & Leaf of Hordeum vulgare & $\begin{array}{l}\text { KF } 1449 \\
07\end{array}$ & $\begin{array}{l}\text { KF1449 } \\
99\end{array}$ & $\begin{array}{l}\text { KF } 1450 \\
41\end{array}$ & & & & \\
\hline & A. phragmites & CPC $18900 *$ & Culms of Phragmites australis & $\begin{array}{l}\text { KF1449 } \\
09\end{array}$ & $\begin{array}{l}\text { KF1450 } \\
01\end{array}$ & $\begin{array}{l}\text { KF1450 } \\
43\end{array}$ & & & & \\
\hline & A. pseudosinense & CPC $21546^{*}$ & Leaf of bamboo & $\begin{array}{l}\text { KF1449 } \\
10\end{array}$ & - & $\begin{array}{l}\text { KF1450 } \\
44\end{array}$ & & & & \\
\hline & $\begin{array}{l}\text { A. } \\
\text { pseudoparenchy } \\
\text { maticum }\end{array}$ & $\begin{array}{l}\mathrm{LC} 7234= \\
\text { WM468 }\end{array}$ & Leaf of bamboo & $\begin{array}{l}\text { KY4947 } \\
43\end{array}$ & $\begin{array}{l}\text { KY7052 } \\
11\end{array}$ & $\begin{array}{l}\text { KY7051 } \\
39\end{array}$ & & & & \\
\hline
\end{tabular}


Table S1 Continued.

\begin{tabular}{|c|c|c|c|c|c|c|c|c|c|c|}
\hline \multirow{2}{*}{ Figs } & \multirow{2}{*}{ Species } & \multirow{2}{*}{ Strain number ${ }^{1}$} & \multirow{2}{*}{ Host } & \multicolumn{7}{|c|}{ GenBank accessions $^{2}$} \\
\hline & & & & ITS & TUB & TEF & RPB2 & $28 S$ & ACT & CAL \\
\hline & & LC8174 & Leaf of bamboo & $\begin{array}{l}\text { KY4947 } \\
54\end{array}$ & $\begin{array}{l}\text { KY7052 } \\
22\end{array}$ & $\begin{array}{l}\text { KY7051 } \\
50\end{array}$ & & & & \\
\hline & & LC8173 & Leaf of bamboo & $\begin{array}{l}\text { KY4947 } \\
53\end{array}$ & $\begin{array}{l}\text { KY7052 } \\
21\end{array}$ & $\begin{array}{l}\text { KY7051 } \\
49\end{array}$ & & & & \\
\hline & $\begin{array}{l}\text { A. } \\
\text { pseudospegazzini } \\
i\end{array}$ & CBS 102052* & $\begin{array}{l}\text { Macaranga hullettii stem } \\
\text { colonised by ants }\end{array}$ & $\begin{array}{l}\text { KF1449 } \\
11\end{array}$ & $\begin{array}{l}\text { KF1450 } \\
02\end{array}$ & $\begin{array}{l}\text { KF1450 } \\
45\end{array}$ & & & & \\
\hline & A. pterospermum & CPC 20193* & $\begin{array}{l}\text { Leaf lesion of Machaerina } \\
\text { sinclairii }\end{array}$ & $\begin{array}{l}\text { KF1449 } \\
13\end{array}$ & $\begin{array}{l}\text { KF1450 } \\
04\end{array}$ & $\begin{array}{l}\text { KF1450 } \\
46\end{array}$ & & & & \\
\hline & A. puccinioides & CBS 549.86 & $\begin{array}{l}\text { Leaf of Lepidosperma } \\
\text { gladiatum }\end{array}$ & $\begin{array}{l}\mathrm{AB} 2202 \\
53\end{array}$ & $\begin{array}{l}\text { AB2203 } \\
00\end{array}$ & - & & & & \\
\hline & A. rasikravindrii & CBS 337.61 & Cissus & $\begin{array}{l}\text { KF1449 } \\
14\end{array}$ & - & - & & & & \\
\hline & & $\begin{array}{l}\text { LC8180 = } \\
\text { LF1684 }\end{array}$ & Bee bread & $\begin{array}{l}\text { KY4947 } \\
60\end{array}$ & $\begin{array}{l}\text { KY7052 } \\
28\end{array}$ & $\begin{array}{l}\text { KY7051 } \\
56\end{array}$ & & & & \\
\hline & & $\mathrm{LC} 8179=$ & & KY4947 & KY7052 & KY7051 & & & & \\
\hline & & LF1737 & Bee bread & 59 & 27 & 55 & & & & \\
\hline & & LC7119 = & Leaf of bamboo & KY4947 & KY7051 & KY7051 & & & & \\
\hline & & WM353 & Leal or bamboo & 24 & 92 & 21 & & & & \\
\hline & & $\begin{array}{l}\text { LC7142 = } \\
\text { WM376 }\end{array}$ & Leaf of bamboo & $\begin{array}{l}\text { KY4947 } \\
35\end{array}$ & KY7052 & KY7051 & & & & \\
\hline & & NFCCI 2144* & Soil & $\begin{array}{l}\text { J5 } \\
\text { JF32645 } \\
4.2\end{array}$ & 03 & 31 & & & & \\
\hline & A. sacchari & CBS 212.30 & Phragmites australis & $\begin{array}{l}\text { KF1449 } \\
16\end{array}$ & $\begin{array}{l}\text { KF1450 } \\
05\end{array}$ & $\begin{array}{l}\text { KF1450 } \\
47\end{array}$ & & & & \\
\hline & & CBS 301.49 & Bamboo & $\begin{array}{l}\text { KF1449 } \\
17\end{array}$ & $\begin{array}{l}\text { KF1450 } \\
06\end{array}$ & $\begin{array}{l}\text { KF1450 } \\
48\end{array}$ & & & & \\
\hline & A. saccharicola & CBS 191.73 & Air & $\begin{array}{l}\text { KF1449 } \\
20\end{array}$ & $\begin{array}{l}\text { KF1450 } \\
09\end{array}$ & $\begin{array}{l}\text { KF1450 } \\
51\end{array}$ & & & & \\
\hline & & CBS 334.86 & $\begin{array}{l}\text { Dead culms of Phragmites } \\
\text { australis }\end{array}$ & $\begin{array}{l}\mathrm{AB} 2202 \\
57\end{array}$ & $\begin{array}{l}\text { KF1450 } \\
10\end{array}$ & $\begin{array}{l}\text { KF1450 } \\
52\end{array}$ & & & & \\
\hline & & CBS 463.83 & $\begin{array}{l}\text { Dead culms of Phragmites } \\
\text { australis }\end{array}$ & $\begin{array}{l}\text { KF1449 } \\
21\end{array}$ & $\begin{array}{l}\text { KF1450 } \\
11\end{array}$ & $\begin{array}{l}\text { KF1450 } \\
53\end{array}$ & & & & \\
\hline
\end{tabular}


Table S1 Continued.

\begin{tabular}{|c|c|c|c|c|c|c|c|c|c|c|}
\hline \multirow{2}{*}{ Figs } & \multirow{2}{*}{ Species } & \multirow{2}{*}{ Strain number ${ }^{1}$} & \multirow{2}{*}{ Host } & \multicolumn{7}{|c|}{ GenBank accessions $^{2}$} \\
\hline & & & & ITS & TUB & TEF & RPB2 & $28 S$ & ACT & CAL \\
\hline & A. serenense & IMI $326869^{*}$ & & $\begin{array}{l}\mathrm{AB} 2202 \\
50\end{array}$ & $\begin{array}{l}\text { AB2202 } \\
97\end{array}$ & - & & & & \\
\hline & A. subglobosum & $\begin{array}{l}\text { MFLUCC 11- } \\
\text { 0397* }\end{array}$ & Dead bamboo culms & $\begin{array}{l}\text { KR0691 } \\
12\end{array}$ & - & - & & & & \\
\hline & A subroseum & $\mathrm{LC} 7215=$ & I eaf of hamboo & KY4947 & KY7052 & KY7051 & & & & \\
\hline & & WM449 & Leat of bamboo & 40 & 08 & 36 & & & & \\
\hline & & $\mathrm{LC7291}=$ & & KY4947 & KY7052 & KY7051 & & & & \\
\hline & & WM525 & Leat of bamboo & 51 & 19 & 47 & & & & \\
\hline & & $\mathrm{LC} 7292=$ & I eaf of hambog & KY4947 & KY7052 & KY7051 & & & & \\
\hline & & WM526 & Leai от bamboo & 52 & 20 & 48 & & & & \\
\hline & A. thailandicum & $\begin{array}{l}\text { MFLUCC 15- } \\
0202 *\end{array}$ & Dead bamboo culms & $\begin{array}{l}\text { KU9401 } \\
45\end{array}$ & - & - & & & & \\
\hline & & I C5630 & Rotten wood & KY4947 & KY8062 & KY7051 & & & & \\
\hline & & LC5030 & Rotten wood & 14 & 00 & 13 & & & & \\
\hline & & & & AB2202 & AB2202 & & & & & \\
\hline & A. urticae & IIVI 326344 & Unknown & 45 & 92 & - & & & & \\
\hline & A xenocordella & & & KF1449 & KF1450 & KF1450 & & & & \\
\hline \multirow{11}{*}{ Fig. 3} & A. xenocoraella & CBS 4/8.86 & So1l from roadwa & 25 & 13 & 55 & & & & \\
\hline & & $\mathrm{I} C 2486$ & Camollia sinonsic & KY4946 & KY7051 & KY7050 & & & & \\
\hline & & LC3480 & camellia sinensis & 87 & 58 & 86 & & & & \\
\hline & A. yunnanum & $\begin{array}{l}\text { MFLUCC 15- } \\
0002 *\end{array}$ & Decaying bamboo culms & $\begin{array}{l}\text { KU9401 } \\
47\end{array}$ & - & - & & & & \\
\hline & Nigrospora & CRS 48073 & & KX9861 & KY0194 & KY0194 & & & & \\
\hline & gorlenkoana & CBS 480.13 & Vitıs vinifera & 09 & 56 & 20 & & & & \\
\hline & Aphanoascus & CBS 466.88 & Soil & AJ3158 & & & & & & \\
\hline & arxii & & & 43 & & & & & & \\
\hline & A. canadensis & UAMH 4574 & & $\begin{array}{l}\text { AJ4394 } \\
35\end{array}$ & & & & & & \\
\hline & A. clathratus & IMI 329400* & Soil & AJ4394 & & & & & & \\
\hline & A. cubensis & $\begin{array}{l}\text { IMI } 356789 \\
\text { FMR 4220* }\end{array}$ & Soil & $\begin{array}{l}\text { AJ4394 } \\
32\end{array}$ & & & & & & \\
\hline
\end{tabular}


Table S1 Continued.

\begin{tabular}{|c|c|c|c|c|c|c|c|c|c|c|}
\hline \multirow{2}{*}{ Figs } & \multirow{2}{*}{ Species } & \multirow{2}{*}{ Strain number ${ }^{1}$} & \multirow{2}{*}{ Host } & \multicolumn{7}{|c|}{ GenBank accessions $^{2}$} \\
\hline & & & & ITS & TUB & TEF & RPB2 & $28 \mathrm{~S}$ & ACT & CAL \\
\hline & A. foetidus & CBS $452.75^{*}$ & Myomys daltoni & $\begin{array}{l}\text { AJ4394 } \\
48\end{array}$ & & & & & & \\
\hline & A. fulvescens & FMR 5652 & & $\begin{array}{l}\text { AJ4394 } \\
37\end{array}$ & & & & & & \\
\hline & A. hispanicus & IMI 335379 & & $\begin{array}{l}\text { AJ4394 } \\
38\end{array}$ & & & & & & \\
\hline & A. keratinophilus & IMI 319010* & Soil & $\begin{array}{l}\text { AJ3903 } \\
80\end{array}$ & & & & & & \\
\hline & A. mephitalis & IMI 151084 & Dung & $\begin{array}{l}\text { AJ4394 } \\
39\end{array}$ & & & & & & \\
\hline & A. pinarensis & $\begin{array}{l}\text { 164FOKM502N } \\
\text { PKJAP } \\
\text { IMI } 360509 \\
\text { FMR 4221* }\end{array}$ & Gallus gallus & $\begin{array}{l}\text { AB8618 } \\
11 \\
\text { AJ4394 } \\
33\end{array}$ & & & & & & \\
\hline & A. punsolae & IMI 334818* & Soil & $\begin{array}{l}\text { AJ4394 } \\
40\end{array}$ & & & & & & \\
\hline & A. reticulisporus & IMI 336466 & Soil & $\begin{array}{l}\text { AJ4394 } \\
41\end{array}$ & & & & & & \\
\hline & A. saturnoideus & CBS 628.88* & Soil & NR_07713 & & & & & & \\
\hline & & IMI $318416^{*}$ & Soil & $\begin{array}{l}\text { AJ4394 } \\
42\end{array}$ & & & & & & \\
\hline & A. terreus & CBS 504.63 & Soil & $\begin{array}{l}\text { AJ4394 } \\
43\end{array}$ & & & & & & \\
\hline & A. verrucosus & IMI 332261 & Soil & $\begin{array}{l}\text { AJ4394 } \\
44\end{array}$ & & & & & & \\
\hline & $\begin{array}{l}\text { Chrysosporium } \\
\text { alvearium }\end{array}$ & $\begin{array}{l}\text { LC11692 = } \\
\text { LF2097 } \\
\text { LC11693 = } \\
\text { LF2098 } \\
\text { LC11684 = } \\
\text { LF1882* }\end{array}$ & $\begin{array}{l}\text { Hive-stored pollen of } B \text {. } \\
\text { campestris } \\
\text { Hive-stored pollen of } B \text {. } \\
\text { campestris } \\
\text { Hive-stored pollen of } B \text {. } \\
\text { campestris }\end{array}$ & $\begin{array}{l}\text { MF9395 } \\
\text { 99 } \\
\text { MF9396 } \\
\text { 00 } \\
\text { MF9395 } \\
\text { 98 }\end{array}$ & $\begin{array}{l}\text { MF9396 } \\
26 \\
\text { MF9396 } \\
27 \\
\text { MF9396 } \\
25\end{array}$ & & $\begin{array}{l}\text { MF9396 } \\
\text { 08 } \\
\text { MF9396 } \\
\text { 09 } \\
\text { MF9396 } \\
\text { 07 }\end{array}$ & $\begin{array}{l}\text { MF9395 } \\
\mathbf{8 1} \\
\text { MF9395 } \\
\mathbf{8 2} \\
\text { MF9395 } \\
\mathbf{8 0}\end{array}$ & & $\begin{array}{l}\text { MF9395 } \\
91 \\
\text { MF9395 } \\
\text { 90 } \\
\text { MF9395 } \\
89\end{array}$ \\
\hline & C. articulatum & UAMH 4320 & & $\begin{array}{l}\text { AJ0078 } \\
41\end{array}$ & & & & & & \\
\hline
\end{tabular}


Table S1 Continued.

\begin{tabular}{|c|c|c|c|c|c|c|c|c|c|c|}
\hline \multirow{2}{*}{ Figs } & \multirow{2}{*}{ Species } & \multirow{2}{*}{ Strain number ${ }^{1}$} & \multirow{2}{*}{ Host } & \multicolumn{7}{|c|}{ GenBank accessions $^{2}$} \\
\hline & & & & ITS & TUB & TEF & RPB2 & $28 \mathrm{~S}$ & ACT & CAL \\
\hline & C. carmichaelii & CBS 643.79* & & $\begin{array}{l}\text { AJ0078 } \\
42\end{array}$ & & & & & & \\
\hline & C. europae & UAMH 4587 & & $\begin{array}{l}\text { AJ0078 } \\
43\end{array}$ & & & & & & \\
\hline & C. evolceanui & RV 26475 & & $\begin{array}{l}\text { AJ0053 } \\
68\end{array}$ & & & & & & \\
\hline & C. filiforme & CBS $187.82^{*}$ & Pinus contorta var. latifolia & $\begin{array}{l}\text { AJ1316 } \\
80\end{array}$ & & & & & & \\
\hline & C. fluviale & FMR 6005 & & $\begin{array}{l}\text { AJ0053 } \\
67\end{array}$ & & & & & & \\
\hline & C. georgii & CBS 272.66* & Soil & $\begin{array}{l}\text { AJ0078 } \\
44\end{array}$ & & & & & & \\
\hline & C. guizhouense & EM14.2002* & Soil & $\begin{array}{l}\text { KT9487 } \\
65\end{array}$ & & & & & & \\
\hline & C. hubeiense & EM66601* & Soil & $\begin{array}{l}\text { KJ8492 } \\
27\end{array}$ & & & & & & \\
\hline & C. indicum & GZUIFR-3-4 & & $\begin{array}{l}\text { HQ6859 } \\
65\end{array}$ & & & & & & \\
\hline & $\begin{array}{l}\text { C. } \\
\text { keratinophilum }\end{array}$ & IFO 7584 & & $\begin{array}{l}\text { AJ1316 } \\
81\end{array}$ & & & & & & \\
\hline & C. linfenense & GZUIFR-H31* & Soil & $\begin{array}{l}\text { FJ39256 } \\
1\end{array}$ & & & & & & \\
\hline & C. lobatum & CBS 666.78* & Apodemus & $\begin{array}{l}\text { AJ1316 } \\
88\end{array}$ & & & & & & \\
\hline & C. longisporum & CBS $133990^{*}$ & $\begin{array}{l}\text { dermic lesion of Erpeton } \\
\text { tentaculatum }\end{array}$ & $\begin{array}{l}\text { HF5478 } \\
73\end{array}$ & & & & & & \\
\hline & C. lucknowense & IMI 112798* & Soil & $\begin{array}{l}\text { AJ1316 } \\
82\end{array}$ & & & & & & \\
\hline & C. magnasporum & CBS $132551^{*}$ & $\begin{array}{l}\text { Catharacta skua Brunnich } \\
\text { pellet }\end{array}$ & $\begin{array}{l}\text { HG3297 } \\
27\end{array}$ & & & & & & \\
\hline & C. mephiticum & CBS $320.86^{*}$ & 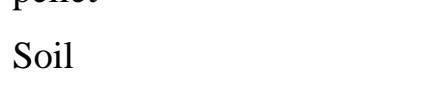 & $\begin{array}{l}\text { AJ1316 } \\
83\end{array}$ & & & & & & \\
\hline
\end{tabular}


Table S1 Continued.

\begin{tabular}{|c|c|c|c|c|c|c|c|c|c|c|}
\hline \multirow{2}{*}{ Figs } & \multirow{2}{*}{ Species } & \multirow{2}{*}{ Strain number ${ }^{1}$} & \multirow{2}{*}{ Host } & \multicolumn{7}{|c|}{ GenBank accessions $^{2}$} \\
\hline & & & & ITS & TUB & TEF & RPB2 & $28 S$ & ACT & CAL \\
\hline & C. merdarium & CBS 408.72* & Dung & $\begin{array}{l}\text { AJ3903 } \\
84\end{array}$ & & & & & & \\
\hline & $\begin{array}{l}\text { C. } \\
\text { minutisporosum }\end{array}$ & IMI 379912 & & $\begin{array}{l}\text { AJ1316 } \\
89\end{array}$ & & & & & & \\
\hline & C. oceanitesii & CBS $132552^{*}$ & $\begin{array}{l}\text { Dead junvenile of Oceanites } \\
\text { oceanicus }\end{array}$ & $\begin{array}{l}\text { HG3297 } \\
29\end{array}$ & & & & & & \\
\hline & C. pilosum & IMI 356294* & River sediment & $\begin{array}{l}\text { AJ3903 } \\
85\end{array}$ & & & & & & \\
\hline & $\begin{array}{l}\text { C. } \\
\text { pseudomerdariu } \\
m\end{array}$ & CBS 631.79* & Beach sand & $\begin{array}{l}\text { AJ3903 } \\
86\end{array}$ & & & & & & \\
\hline & C. qinghaiense & GZUIFR-11* & Soil & $\begin{array}{l}\text { JX8686 } \\
07\end{array}$ & & & & & & \\
\hline & $\begin{array}{l}\text { C. } \\
\text { queenslandicum }\end{array}$ & IFM 51121 & Soil & $\begin{array}{l}\mathrm{AB} 2192 \\
28\end{array}$ & & & & & & \\
\hline & C. sanyaense & $\begin{array}{l}\text { GZUIFR- } \\
\text { A10222M* }\end{array}$ & Rhizosphere Soil of palm & $\begin{array}{l}\text { JQ8092 } \\
69\end{array}$ & & & & & & \\
\hline & C. siglerae & UAMH $6541^{*}$ & Soil & $\begin{array}{l}\text { AJ1316 } \\
84\end{array}$ & & & & & & \\
\hline & C. speluncarum & CCF 3761 & Bat guano & $\begin{array}{l}\text { AM949 } \\
569\end{array}$ & & & & & & \\
\hline & & CCF $3760^{*}$ & Guano of Rhinolophus euryale & $\begin{array}{l}\text { AM949 } \\
568\end{array}$ & & & & & & \\
\hline & C. submersum & IMI 379911* & River sediment & $\begin{array}{l}\text { AJ1316 } \\
86\end{array}$ & & & & & & \\
\hline & C. sulfureum & CBS 634.79 & Cheese rind & $\begin{array}{l}\text { AJ3903 } \\
87\end{array}$ & & & & & & \\
\hline & C. tropicum & UAMH 691 & & $\begin{array}{l}\text { AJ1316 } \\
85\end{array}$ & & & & & & \\
\hline & C. undulatum & IMI 375884* & Soil & $\begin{array}{l}\text { AJ0078 } \\
45\end{array}$ & & & & & & \\
\hline & C. vallenarense & $\begin{array}{l}\text { CBS 627.83, } \\
\text { ATCC 64421* }\end{array}$ & Keratinous substrate & $\begin{array}{l}\text { AJ3903 } \\
89\end{array}$ & & & & & & \\
\hline
\end{tabular}


Table S1 Continued.

\begin{tabular}{|c|c|c|c|c|c|c|c|c|c|}
\hline \multirow{2}{*}{ Figs } & \multirow{2}{*}{ Species } & \multirow{2}{*}{ Strain number ${ }^{1}$} & \multirow{2}{*}{ Host } & \multicolumn{6}{|c|}{ GenBank accessions $^{2}$} \\
\hline & & & & ITS $\quad$ TUB & TEF & RPB2 & $28 S$ & ACT & CAL \\
\hline \multirow{27}{*}{ Fig. 4} & C. vespertilium & RV 27093 & & $\begin{array}{l}\text { AJ0078 } \\
46\end{array}$ & & & & & \\
\hline & & & & AB2192 & & & & & \\
\hline & C. zonatum & IFM 51122 & Soil & 29 & & & & & \\
\hline & Corynascus & FMR 5593 & & AJ4394 & & & & & \\
\hline & & & & 47 & & & & & \\
\hline & $\begin{array}{l}\text { Thermothelomyc } \\
\text { es thermophila }\end{array}$ & H127-1 & Soil & $\begin{array}{l}\text { JX8686 } \\
06\end{array}$ & & & & & \\
\hline & Nigrograna & HKAS 83978* & Submeroed wood & KY5110 & KY5110 & - & KY5110 & & \\
\hline & cangshanensis & ПКАМ О5YГО & & 63 & & - & 64 & & \\
\hline & & & Dead branches of Sambисиs & KX6505 & KX6505 & KX6505 & KX6505 & & \\
\hline & N. fuscidula & CBS $1414 / 6$ & nigra & 47 & 22 & 76 & & & \\
\hline & & CRS $141556 *$ & Dead branches and twigs of & KX6505 & KX6505 & & KX6505 & & \\
\hline & & CBS $141556^{*}$ & Sambucus nigra & 50 & 25 & & 50 & & \\
\hline & N. locuta- & LC11685 = & Hive-stored pollen of $B$. & MF9396 & MF9396 & MF9396 & MF9395 & & \\
\hline & pollinis & LF1889* & campestris & 01 & 13 & & 83 & & \\
\hline & & $\mathrm{LC11690}=$ & Hive-stored pollen of $B$. & MF9396 & MF9396 & MF9396 & MF9395 & & \\
\hline & & LF2070 & campestris & 02 & 14 & 11 & 84 & & \\
\hline & & LC11691 = & Hive-stored pollen of $B$. & MF9396 & MF9396 & MF9396 & MF9395 & & \\
\hline & & LF2071 & campestris & 03 & 15 & 12 & 85 & & \\
\hline & N. mackinnonii & CBS 110022 & Man, mycetoma of patient & KF0156 & $\begin{array}{l}\text { KF4079 } \\
85\end{array}$ & KF0157 & GQ3876 & & \\
\hline & & & & & $\begin{array}{l}\text { KJ } \\
\text { KF4079 }\end{array}$ & KF0157 & GQ3876 & & \\
\hline & & CBS $674.75^{*}$ & Man, black grain mycetoma & NR_132037 & 86 & & 13 & & \\
\hline & & F9303e & Malvaviscus concinnus & JN5457 & LN6266 & LN6266 & LN6266 & & \\
\hline & & E95030 & Matvaviscus conctinnus & 59 & 73 & 66 & 81 & & \\
\hline & N. mycophila & CBS $141478^{*}$ & Twigs of Acer campestre & KX6505 & KX6505 & - & KX6505 & & \\
\hline & & & & $\begin{array}{l}53 \\
\text { KX6505 }\end{array}$ & $\begin{array}{l}26 \\
\text { KX6505 }\end{array}$ & & KX6505 & & \\
\hline & & MF6 & Corylus avellana & $\begin{array}{l}\text { NAOJUJ } \\
54\end{array}$ & & - & 54 & & \\
\hline & & CBS 141483 & Twigs of Acer pseudoplatanus & $\begin{array}{l}\text { KX6505 } \\
55\end{array}$ & $\begin{array}{l}\text { KX6505 } \\
28\end{array}$ & $\begin{array}{l}\text { KX6505 } \\
77\end{array}$ & $\begin{array}{l}\text { KX6505 } \\
55\end{array}$ & & \\
\hline
\end{tabular}


Table S1 Continued.

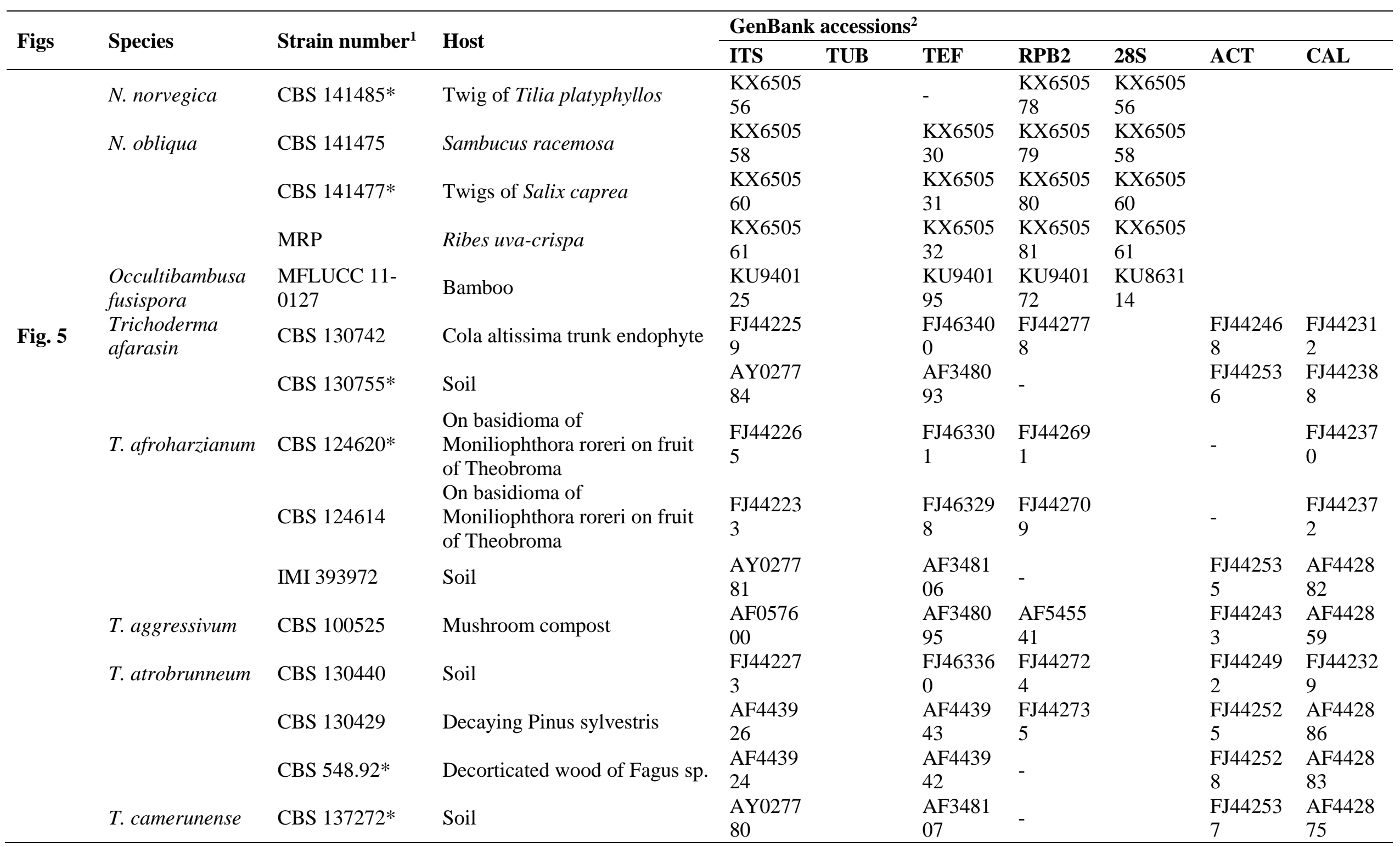


Table S1 Continued.

\begin{tabular}{|c|c|c|c|c|c|c|c|c|c|c|}
\hline \multirow{2}{*}{ Figs } & \multirow{2}{*}{ Species } & \multirow{2}{*}{ Strain number ${ }^{1}$} & \multirow{2}{*}{ Host } & \multicolumn{7}{|c|}{ GenBank accessions $^{2}$} \\
\hline & & & & ITS & TUB & TEF & RPB2 & $28 S$ & ACT & CAL \\
\hline & \multirow{6}{*}{ T. endophyticum } & \multirow{2}{*}{ G.J.S. 99-231 } & \multirow{2}{*}{ Soil } & AY0277 & & AF3481 & \multirow[b]{2}{*}{ - } & & FJ44253 & AF4428 \\
\hline & & & & 83 & & 08 & & & 8 & 74 \\
\hline & & \multirow{2}{*}{ CBS $130729 *$} & Theobroma gileri trunk & FJ44224 & & FJ46331 & \multirow[b]{2}{*}{ - } & & FJ44244 & FJ44229 \\
\hline & & & endophyte & 3 & & 9 & & & 5 & 2 \\
\hline & & \multirow{2}{*}{ CBS 130730} & Theobroma gileri trunk & FJ44224 & & FJ46331 & \multirow{2}{*}{\multicolumn{2}{|c|}{$\begin{array}{l}\text { FJ44272 } \\
1\end{array}$}} & FJ44244 & FJ44229 \\
\hline & & & endophyte & 2 & & 4 & & & 6 & 3 \\
\hline & \multirow{4}{*}{ T. guizhouense } & \multirow{2}{*}{ DAOM 231435} & \multirow{2}{*}{ Soil } & EF1912 & & EF1913 & \multirow{2}{*}{\multicolumn{2}{|c|}{-}} & \multirow[b]{2}{*}{-} & \multirow{2}{*}{$\begin{array}{l}\text { FJ57772 } \\
1\end{array}$} \\
\hline & & & & 96 & & 21 & & & & \\
\hline & & \multirow{2}{*}{ CBS $131803 *$} & \multirow{2}{*}{ Soil } & JN1913 & & JN2154 & \multirow{2}{*}{\multicolumn{2}{|c|}{$\begin{array}{l}\text { JQ9014 } \\
00\end{array}$}} & - & - \\
\hline & & & & 11 & & 84 & & & - & - \\
\hline & \multirow{6}{*}{ T. harzianum } & \multirow{2}{*}{ CBS 226.95* } & \multirow{2}{*}{ Soil } & $\mathrm{AJ} 2227$ & & AF3481 & \multicolumn{2}{|l|}{ AF5455 } & FJ44256 & AF4428 \\
\hline & & & & 20 & & 01 & 49 & & 7 & 64 \\
\hline & & \multirow{2}{*}{$\begin{array}{l}\text { CBS } 1304452= \\
\text { G.J.S. 04-71 }\end{array}$} & Costaner sativa twio endonhyte & FJ44267 & & FJ46339 & FJ44277 & & FJ44249 & FJ44236 \\
\hline & & & Castanea sativa twig endopnyte & 3 & & 6 & 9 & & 4 & 9 \\
\hline & & CBS $130496=$ & Ricinus communis stem & FJ44267 & & FJ46332 & FJ44270 & & FJ44256 & FJ44233 \\
\hline & & G.J.S. 05-107 & endophyte & 9 & & 9 & 8 & & 9 & 3 \\
\hline & & & & FJ44268 & & AF3480 & FJ44272 & & FJ44256 & AF4428 \\
\hline & 1. Inhamatum & CBS $213.18^{\circ}$ & So1l & 0 & & 99 & 5 & & 1 & 91 \\
\hline & & G.J.S. 09-697 & Soil & - & & $\begin{array}{l}\text { KP1152 } \\
72\end{array}$ & - & & - & - \\
\hline & $T$ lontiform & CDS 130726 & Theobroma cacao trunk & FJ44268 & & FJ85187 & FJ44278 & & FJ44244 & FJ44228 \\
\hline & 1. lenijorme & CDS $150 / 20$ & endophyte & 1 & & 2 & 6 & & 0 & 7 \\
\hline & & CBS $100542 *$ & Decorticated wood & AF4691 & & AF4691 & _ & & AF4691 & AF4691 \\
\hline & & & & 89 & & 95 & - & & 93 & 91 \\
\hline & $T$ lixii & CBS $110080 *$ & Decayed Ganoderma & AF4439 & & AF4439 & & & FJ44253 & AF4428 \\
\hline & 1. $l i x u l$ & CBS $110080^{*}$ & basidiocarp & 20 & & 38 & - & & 3 & 72 \\
\hline & $T$ neotropicale & G IS 11-185* & Hevea guianensis trunk & HQ0224 & & HQ0227 & & & KP1152 & KP1152 \\
\hline & & & endophyte & 07 & & 71 & - & & 68 & 79 \\
\hline & $T$ nollinicola & $\mathrm{LC11682}=$ & Newly-collected pollen of $B$. & MF9395 & & MF9396 & MF9396 & & & MF9395 \\
\hline & 1.pollinicola & LF1542* & campestris & 92 & & 19 & 04 & & - & 86 \\
\hline & & LC11686 = & Newly-collected pollen of $B$. & MF9395 & & MF9396 & MF9396 & & & MF9395 \\
\hline & & LF2050 & campestris & 93 & & 20 & 05 & & - & 87 \\
\hline
\end{tabular}


Table S1 Continued.

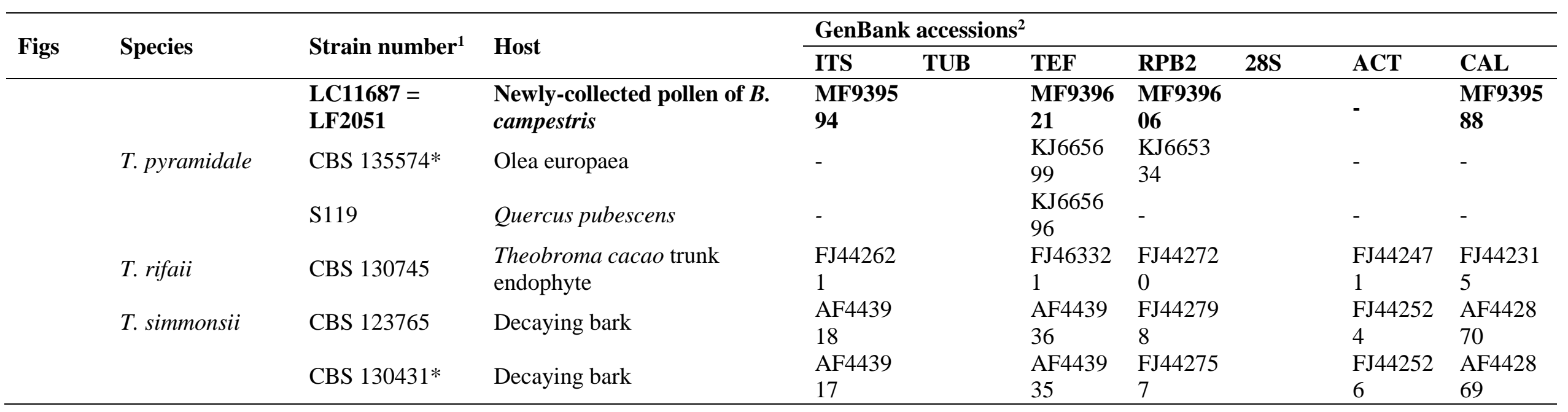

${ }^{1}$ ATCC: American Type Culture Collection, Manassas, VA, USA; CBS: Culture Collection of the Westerdijk Fungal Biodiversity Institute, Utrecht, The Netherlands; CGMCC: China General Microbiological Culture Collection, Institute of Microbiology, Chinese Academy of Sciences, Beijing, China; FMR: Facultat de Medicina i Ciències de la Salut, Reus, Spain; IFO: Institute for Fermentation, Osaka, Japan; IMI: Culture collection of CABI Europe UK Center, Egham, UK; MFLUCC: Mae Fah Luang University Culture Collection, Chiang Rai Thailand; LC: working collection of Lei Cai, housed at the Institute of Microbiology, Chinese Academy of Sciences, Beijing, China; UAMH: Centre for Global Microfungal Biodiversity, University of Toronto, Toronto, Canada;

${ }^{2}$ Sequences newly generated in this study are indicated in bold. 